\title{
İyi uygulamalar çerçevesinde bütçe ilkeleri ve örnek ülke incelemeleri*
}

Abdulkerim EROĞLU ${ }^{1}$

(1D) Haluk EGELİ ${ }^{2}$

\begin{abstract}
\begin{tabular}{lll}
\hline $\begin{array}{l}\text { Araştırma Makalesi } \\
\text { Gönderi Tarihi:17.11.2020 }\end{array}$ & Kabul Tarihi: 09.12 .2020 & DOI: https://doi.org/10.51177/kayusosder.827330 \\
Online Yayın Tarihi: 31.12 .2020
\end{tabular}
$\ddot{O} \mathbf{z}$

Bütçe ilkeleri bütçeleme sürecinin bir bütün olarak ele alındığı durumda bütçelemenin felsefesini ortaya koymaktadır. Böylelikle anayasa kurucularının, yasama ve yürütmenin devlet idaresinin en önemli araçlarından olan bütçeyi nasıl değerlendirdikleri ortaya çıkmaktadır. Bu vesileyle hem anayasal hem de yasal seviyede kabul edilen bütçeleme ilkeleri mali sistemin tamamı üzerinde etkili olmaktadır. Çalışmada bu gerçek göz önüne alınarak bütçe ilkeleri uygulamalarında örnek teşkil edebilecek ülkeler incelenmiştir. Ülke seçimlerinde uluslararası kıyaslamaya imkân verecek Açık Bütçe Endeksinin sayısal göstergeleri etkili olmuştur.
\end{abstract}

Anahtar Kelimeler: Bütçe İlkeleri, Bütçeleme Süreci, Açık Bütçe Endeksi

\section{Budget principles in the framework of good practices and case studies of selected countries}

\begin{abstract}
Budget principles reveal the philosophy of budgeting when the budgeting process is considered as a whole. Thus, it is revealed how constituiton makers, legislature and executive branches evaluate the budget which is one of the most important tools of government administration. Hereby, the budgeting principles that accepted both at the constitutional and legal level have affect on the entire financial system. Taking this fact into consideration the countries that can be good examples of implementation of budget principles have examined in this study. Indicator of the Open Budget Index which allow international comparison have been effective in the country selection.
\end{abstract}

Key Words: Budget Principles, Budgeting Process, Open Budget Index

\section{Giris}

Bütçe ilkeleri bütçeleme sürecinin nasıl işleyeceğinin genel çerçevesini ve temel kaidelerini ifade eder. Dolayısıyla yukarıdan aşağıya doğru her seviyede işletilecek bütçe süreci buradaki temel kaideler kapsamında ele alınmak mecburiyetindedir. Bu mecburiyet devlet bütçesi veya daha dar anlamda ve burada ele alınacak şekliyle merkezi yönetim bütçesi gibi kapsamlı bir belgenin belli bir disiplin içinde değerlendirilmesini de garanti altına almaktadır. Ancak burada bahsi geçen ilkelerin genel bir çerçeve sunmaları dolayısıyla farklı şekilde yorumlanmaları gibi olumsuz durumlar meydana gelebilmektedir. Böyle bir olasılık ise bütçe ilkelerinin salt bir temenniden ziyade yasal alt yapılarının ikincil mevzuatlarla güçlendirilmesine, kişisel yorumlarla suiistimale yol açacak değerlendirmelerin ortadan kaldırılmasına, ilkelere uyumun denetleyici kurumların garantisi altına alınmasına ve gerektiğinde yaptırımlar dahilinde korunmasına, yasama organının yürütme organını denetleme kriteri olarak kullanmasına kadar bir dizi önlemin alınmasını şart koşmaktadır.

\footnotetext{
*Bu çalışma Dokuz Eylül Üniversitesi Sosyal Bilimler Enstitüsü, Prof. Dr. Haluk EGELİ danışmanlığında hazırlanan ve henüz savunması gerçekleşmemiş olan “Türkiye'de Merkezi Yönetim Bütçe Sürecinin İlkesel ve Kurumsal Analizi” isimli tezden üretilmiştir.

${ }^{1}$ Araştırma Görevlisi, Dokuz Eylül Üniversitesi, İktisadi ve İdari Bilimler Fakültesi, Maliye Bölümü, abdulkerim.eroglu@ deu.edu.tr

${ }^{2}$ Prof. Dr., Haluk EGELİ, Dokuz Eylül Üniversitesi, İktisadi ve İdari Bilimler Fakültesi, Maliye Bölümü, haluk.egeli@deu.edu.tr
} 
Bütçeleme süreci bir bütün olarak bütçe taslağının hazırlanması, bu taslağın görüşülüp onaylanması ve kanunlaşması, bütçenin uygulanması, uygulama sürecinin izlenmesi, uygulama sonrası denetiminin yapılmasından meydana gelmektedir. Dolayısıyla ve tabii olarak bazı bütçe ilkeleri bütçeleme aşamalarından bir kısmında ön plana çıkarken bazıları ise diğer kısmında ön plana çıkmaktadır. Ancak kimi bütçe ilkeleri, örneğin mali saydamlık gibi, bütçeleme sürecinin tüm aşamalarında ön planda olmak durumundadır. Bu bakımdan tüm süreç boyunca önemini koruyan bunun gibi bütçe ilkeleri diğer bütçe ilkelerinin önemli bir garantörü konumuna gelmektedir. Başka bir deyişle mali saydamlık ve/veya bütçe hakkı (bütçe hakkının ilkesel yönü konusunda bkz. Kıral ve Demir, 2019) gibi bütçe ilkelerine riayet edilmediği durumlarda hesap verilebilirlik ve doğruluk gibi bütçe ilkelerinin anlamlılık düzeyi önemli ölçüde gerilemektedir. Bununla birlikte hiçbir bütçe ilkesi diğer bütçe ilkelerinden daha az önemli olarak değerlendirilmemelidir. Çalışmada bütçe ilkelerinin kavramsal boyutuna değinildikten sonra seçilmiş ülke uygulamaları çerçevesinde bir değerlendirmeye gidilmiştir.

\section{Bütçe ilkeleri}

Kamu sektörünün büyümesi, bütçe konusunda teknik detayların artması/karmaşılaşması ve bürokratik süreçlerin genişlemesi yürütme organının bütçe sorumluluklarını arttırmıştır. 20. yüzyılda parlamentolar bütçelemede yaşanan bu gelişmeler karşısında güçlükler yaşamıştır. Yürütme organlarının bütçe konusunda sahip olduğu bilgi birikimi ve uzmanlık seviyesi ile karşılaştırıldığı yasama organlarının buna ayak uyduramadığ görülmüş̧ür (Posner ve Park, 2007, s. 5). Bu bakımdan bütçeden beklenilen fonksiyonlar yerine getirilmeye çalış1ırken aynı zamanda da parlamentoların ve dolaylı olarak vatandaşların bu süreçteki enformatik açıdan geri kalmışlığını telafi etmek ve süreci disiplin altına almak için bütçe ilkeleri benimsenmiştir. Bahsi geçen bütçe ilkeleri; klasik bütçe ilkeleri ve modern bütçe ilkeleri olmak üzere iki başlık altında incelenecektir.

\subsection{Klasik Bütçe Illkeleri}

Genellik ilkesi devlete ait tüm gelir ve giderlerin bütçede gösterilmesini ifade eder. Bununla birlikte genellik ilkesinin gayri safi ve adem-i tahsis olmak üzere iki temel unsuru bulunmaktadır. Gayri safi usulle bazı kamu giderlerinin gelirlerin arkasına saklanmasına müsaade edilmez. Adem-i tahsis usulü ise tahsis usulünün olmamasını gerektirmektedir. Böylece bazı gelirlerin belirli giderler için ayrılmasına müsaade edilmez; yapılacak harcamalar toplam gelir havuzundan finanse edilir.

Bütçede birlik ilkesi devlet gelir ve giderlerinin tek bir bütçede gösterilmesini ifade eder. Birlik ilkesi tek bir bütçe dışında gelir toplanmasına ve harcama yapılmasına müsaade etmez. Dolayısıyla devlet faaliyetlerinin tek bir belge üzerinden izlenmesine imkan vermektedir. Birlik ilkesi bütçenin denk olup olmadığını anlamaya imkan veren yegane ilkedir. Zira devlet gelir ve giderleri birden fazla bütçeye taksim edildiğinde bütçe açığı bunlardan biri veya birkaçı içinde kaybolacaktır (Taşlıyük, 1964, s. 60).

Açıklı ilkesi bütçe ve ilgili diğer belgelerin herkesin anlayabilmesini ifade eder. Bütçelerin istisnasız herkes tarafından anlaşılması, yorumlanması ve eleştirilebilmesi açıklık ilkesinin tam manasıyla benimsendiğini göstermektedir.

Denklik ilkesi temel olarak bütçe gelir ve giderlerinin denk olmasını ifade etmektedir. Özellikle klasik maliyecilerin bir savunusu olan bütçede denklik ilkesi sadece bütçenin açık olmasına değil; aynı zamanda fazla verilmesine de karşıdır. Devletin artan fonksiyonları, halkın beklentilerinde meydana gelen gelişmeler denklik ilkesinin eski öneminin kaybolmasına yol açmıştır (Türk, 1979, s. 286).

Doğruluk ilkesi bütçe tahminine ilişkin olarak yapılacak doğru ve dürüst değerlendirmeleri kapsamaktadır. İlke kavramsal açıdan sübjektif doğruluk ile objektif doğruluk ilkelerinin birleştirilmesiyle meydana gelmiştir (Edizdoğan ve Çetinkaya, 2015, s. 56).

Bütçe, bir mali dönem için yasama organı tarafından yürütme organına gelirlerin toplanması ve harcamaların yapılması için verilen izin olduğu için, ilgili mali dönem henüz başlamadan önce bu iznin verilmesi gerekmektedir. Bu önceden izin alma ilkesi olarak ifade edilmektedir.

Ödenek ayrılması ilkesi tüm kamu gelirleri karşl1ık gösterilmek üzere her hizmet için bir ödenek tahsis edilmesine ifade eder. Ancak buradaki ödenek ayrılması ilkesi sadece harcamalarla ilgili bir husustur. Yukarıda anılan genellik ilkesinin karşıtı bir ilke değildir. Genellik ilkesinde temel 
hususlardan biri belli gelirlerin belli harcamalara tahsis edilmemesine dayanmaktadır. Buradaki genellik ilkesinin de bir sonucu olarak tüm gelirler karşıllk gösterilmek üzere her bir hizmet türüne ödenek ayrılması bütçede tahsis (ödenek ayrılması) ilkesini ifade etmektedir (Aksoy, 1993, s. 225).

Ylllık olma ilkesi, bütçenin mali yılda uygulanması ve uygulama döneminin belirlenmesi açıdan önem arz eden bir ilkedir. Özellikle mevsimsel döngülerin dikkate alınarak bütçe uygulamasının bir yıl olarak sınırlanması ve böylece devlet idaresi için yapılacak harcamaların ve bu harcamaları finanse edecek gelirlerin toplanması belli hususlar çerçevesinde gerçekleşebilecektir.

Anlaşılır olma ilkesi açıklık ilkesinin anlamlılık seviyesini arttıran bir ilkedir (Edizdoğan ve Çetinkaya, 2015, s. 53). Bütçe ve ilgili belgelerin kamuoyuyla paylaşılmasının yanından bunların anlaşılabilir nitelikte olması bu ilkenin bir gereği olarak kabul edilmektedir.

Tasarruf ilkesi, Klasik maliyecilerin devlet yönetiminde verimsizliğin olduğu yönündeki düşüncelerinden hareketle oluşturdukları bir ilkedir. Kamu gelirlerinin etkin ve verimli kullanılması gerektiği savunulur (Edizdoğan ve Çetinkaya, 2015, s. 55).

Aşağıdan-yukarıya (bottom-up) bütçeleme ilkesi bakanlıkların (harcama birimlerinin) kendi ödenek taleplerini hazırlayarak Maliye Bakanına göndermeleri şeklinde işlemektedir. Bu süreçte ödenek talepleri genellikle harcamacı bakanlıkların elde etmeyi bekledikleri fon miktarından daha fazla olmaktadır. Aşağıdan-yukarıya bütçelemenin en önemli aşamalarından biri de bu aşamada meydana gelen harcamacı bakanlıklarla Maliye bakanlığı arasında yapılan görüşmeler/pazarlıklardır (Kim ve Park, 2006, s. 91).

\subsection{Modern Bütçe İlkeleri}

Toplama ilkesi devletlerin artan fonksiyonları ve idari yapılarında meydana gelen gelişmelerin bir sonucu olarak bütün gelir ve giderlerin tek bir bütçede toplanmasının zorlaşmasıyla ortaya çıkmıştır. Toplama ilkesi devlet genel yönetimine yönelik tek bir bütçe olması gerektiğini varsaymaz. Ancak farklı bütçeler ve hesaplar olsa dahi bunların bir araya getirilmesini gerektirir. Buna göre bütçe kanunu hazırlanırken veya mali yıl başlarken farklı bütçeler ve hesaplar olsa dahi yılsonunda bunların bütün olarak görülmesine imkan verecek şekilde toplanmaları gerekmektedir (Aksoy, 1993, s. 227).

Çok yıllı olma ilkesi bütçelerin birden fazla yıl için hazırlanmasını ifade etmektedir. Yıllar itibariyle meydana gelebilecek ekonomik belirsizliklere karşı bir önlem olarak düşünülebilen çok yıllı olma ilkesinden sonraki dönemler için de bir tahmin aracı olarak faydalanmak mümkündür.

Mali disiplin ilkesi kamu maliyesinde gelirler ve giderler arasındaki dengeyi ifade etmektedir. Ancak sadece bu tanımlamadan hareket edilerek ülkelerin mali disiplini sağlama derecelerini ölçmek oldukça zordur. Zira bu tanıma göre gelir ve gider arasındaki dengeyi sağlamış bir ülke örneği göstermek neredeyse imkansızdır. Ancak yine de ülkelerin mali disiplini sağlamak için kendilerine hedef koymaları ve bu yönde girişimlerde bulunmaları mali disiplin kavramının daha geniş bir perspektiften ele alınmasını gerektirmektedir (Hemming, 2004, s. 2; Tandırcıoğlu, 2008, s. 429).

Bütçe hakkl ilkesi devletin hangi alanlara ve ne kadar para harcaması gerektiğine, bu harcamaların finansmanı için halkın ne kadar fedakarlıkta bulunacağına (ödeyeceği vergi miktarına) millet adına parlamentonun söz sahibi olmasını ifade eder (Biçer ve Şahin, 2008, s. 28).

Yukarıdan-aşağıya (top-down) bütçeleme ilkesi 1990'lı yılların başında çok sayıda OECD (Ekonomik Kalkınma ve İşbirliği Örgütü- The Organisation for Economic Co-operation and Developlement) üye ülkelerinde yaşanan bütçe açıklarının yol açtığı mali krizler neticesinde dikkat çekmeye başlamıştır (Kim ve Park, 2006, s. 88). Yukarıdan aşağıya bütçeleme harcamaların miktar ve harcama kalemleri bakımından nasıl tahsis edileceği belirlenmeden önce üst harcama limitinin belirlenmesini gerektiren bir süreçtir. Harcamaların bir sonraki bölümde tahsis edilmeden önce tavanı belirlenir ve bu harcama tavanı sınırı içinde tahsis işlemi gerçekleştirilir (Şahin ve Temur, 2015, s. 146).

Hesap verilebilirlik ilkesi üzerine alınan sorumluluğun cevaplandırılması zorunluluğu ile ilgilidir. Hesap verme sorumluluğu, devlet tarafindan elde edilen kamu gelirinin toplum yararına kullanılmasının güvencesidir. Sahip oldukları yetkiyi kullananlar, bu sorumlulukları gereği bilgi ve hesap vermek durumundadır (Çağan, 2008, s. 191). Buradaki temel ilişki yasama organı ile yürütme organı arasındadır. $\mathrm{Bu}$ durum iki kurum arasında bir raporlama ilişkisi gerektirmektedir. Raporlama 
ilişkisi de denetçiler tarafindan yapılmaktadır. Denetçiler gerçekleşen performansı bağımsız bir şekilde inceler ve yasama organına beklentilere ve performansa yönelik her türlü değişkenlere ilişkin raporlar sunar (Sahgal, 2008, s. 154).

Vatandaş katılımlı hesap verilebilirlik ilkesi yönetişim sürecinin bir parçası olarak vatandaşların denetim sürecinde alacakları rolü ifade etmektedir. Teknoloji ve iletişim araçlarındaki hızlı gelişme hesap verilebilirlik sürecine vatandaşların katılımını desteklemektedir. (Baimyrzaeva ve Kose, 2014, s. $80)$.

Mali saydamlık ilkesi mali disiplin ve mali sorumluluk kurallarına uyulup uyulmadı̆̆ının parlamentolar tarafından denetlenmesini gerektirmektedir. Yürütme organı ile yasama organı arasında ortaya çıkacak yetki devri sonrası bilgi asimetrisi yasama organı aleyhine bir durum meydana getirmektedir. Bunu önlemenin etkin yollarından birisi de mali saydamlığı sağlamaktır (Sak, 2008, ss. 351-352).

\section{Seçilmiş ülkelerin bütçe ilkeleri kapsamında değerlendirilmesi}

Bu kısımda ülke örnekleri ele alınmaktadır. Bu ülkelerin seçilmesinde ele alınan temel kriter bütçe ilkeleri bakımından sahip olunan iyi uygulamalar olmuştur. Bu uygulamalarla diğer ülkelere kıyasla iyi bir dereceye sahip olan ülkeler incelenmiştir. Özellikle Uluslararası Bütçe Ortaklığı tarafından düzenli olarak hazırlanan Açık Bütçe Endeksinde yüksek derece alan ülkeler çalışma kapsamına alınmıştır.

\subsection{Avustralya}

17 Nisan 1998 tarihli Bütçe Dürüstlük Kanunu (The Charter of Budget Honesty Act) hükümetin politikalarını oluşturması için gerekli düzenlemeleri ve ilkeleri içermektedir. Kanunun temel amacı maliye politikasının sonuçlarının iyileştirilmesidir. Bu bağlamda mali politikaların ve performansının kamu denetimini sağlayacak sağlam mali yönetim ilkelerine dayanan mali stratejilerin belirlenmesi hedeflenmiştir. Mali risklerin ve devlet borcunun ihtiyatlı seviyede sürdürülmesi, ulusal tasarrufun yeterli seviyeye getirilmesi, konjonktürel dalgalanmaların ve bu dalgalanmaların hükümetin mali pozisyonu üzerindeki riskinin yönetilmesi, öngörülebilir ve istikrarlı harcama ve vergi politikalarının yürütülmesi, vergi sisteminin bütünlügünün korunması, politika kararlarının gelecek nesiller üzerindeki etkilerinin dikkate alınması bu hedefler için dikkate alınan hususlardır.

Hazinedar bütçeden önce mali strateji tablolarını hazırlamak ve kamuoyuyla paylaşmak durumundadır. Hükümetin mali stratejileri konusunda kamuoyunun farkındalığını arttırmak ve hükümetin yürüttüğü maliye politikasının değerlendirilmesine imkan sağlamak tabloların önemli fonksiyonları arasında yer almaktadır (Bütçe Dürüstlük Kanunu, Madde 6). Mali strateji tabloları ile gerçekleştirilmek istenenlerin içinde; hükümetin uzun vadeli amaçlarının kısa vadeli mali politikalarla çerçevelemek, bütçenin temel oluşturacağı stratejik öncelikleri belirlemek, bütçe y1lı ve takip eden üç yıllık mali yıl için hükümetin mali amaç ve hedefleri ile özel mali önlemlerin beklenen sonuçlarını belirlemek yer almaktadır (Bütçe Dürüstlük Kanunu, Madde 9). Hazinedarın bütçe konusunda hazırlamakla yükümlü olduğu bir diğer belge de ekonomik ve mali görünüm raporudur. Raporun oluşturulmasında devletin birimleri talep edilen bilgileri Hazinedara vermek durumundadır ${ }^{1}$. Rapor dış denetime temel oluşturmak ve dış denetimin standartları ile ilgili genel tanımlamalar getirmek konusunda önem taşımaktadır. Hazinedar tarafından hazırlanan diğer belgeler arasında yarıyıl ve yılsonu bütçe sonuç raporları yer almaktadır. Yarıyıl raporu ile bütçenin mali ve ekonomik görünüm durumu konusundaki son gelişmeleri, vergi harcamalarının detayları ve borç durumu hakkında bilgi paylaş1ır. Yarıyıl raporu da ekonomik ve mali görünüm raporu gibi dış denetime temel oluşturmakta ve dış denetim standartları konusunda genel tanımlar getirmektedir (Bütçe Dürüstlük Kanunu, İkinci Bölüm). Nihai bütçe sonuç raporu (yılsonu bütçe raporu) da mali y1l boyunca gerçekleşen bütçe işlemlerini ele alan bir rapordur. Raporun mali yıl bitimini takip eden üç ay içinde hazırlanıp kamuoyuyla paylaşılması gerekmektedir (Bütçe Dürüstlük Kanunu, Üçüncü Bölüm).

Denetçi Genel Kanunu (1997) ile Genel Denetim Ofisine kurumların ve programların mali ve performans denetimlerini yapması ve parlamentoyu bu konuda bilgilendirmesi görevi verilmiştir. Performans raporları kalite, kapsam ve performans bilgilendirmeyle alakalı bilgi sistemleri üzerinden yapılmaktadır. Performans bilgileri bütçe oluşturulurken, özellikle harcamalar ve programlar gözden 
geçirildiğinde dikkate alınmaktadır (Hawke, 2007, s. 7, 10). Genel Denetim Ofisinin denetim ile ilgili görevleri esas olarak Kamu Yönetimi, Performans ve Hesap Verilebilirlik Kanunu (2013) ile düzenlenmiştir (Denetçi Genel Kanunu, Kısım Dört, Bölüm Bir). Söz konusu kanunla tutarlı bir yönetişim ve hesap verilebilirlik sistemi oluşturmak, kurumlar için performans çerçevesi oluşturmak, yönetim, performans ve hesap verilebilirlikle ilgili yüksek standartlar geliştirmek, kamuoyuna ve parlamentoya anlaşılabilir bilgiler sunmak, kamu kaynaklarının uygun kullanım ve yönetimini sağlamak, devlete ait iktisadi teşekküllerin yönetim, performans ve hesap verilebilirlikle ilgili standartlarını yükseltmek gibi amaçlar belirlenmiştir (Kamu Yönetim, Performans ve Hesap Verilebilirlik Kanunu, Kısım Bir, Bölüm İki).

Yukarıda değinilen Gözden Geçirme Komitesi sadece bütçe hazırlama sürecinde yer almamaktadır. Aynı zamanda bütçenin uygulanması sırasında da sürece dahil olmaktadır. Bununla birlikte Komiteye verilen bir diğer sorumluluk da önceki hükümetin yaptı̆̆ 1 harcamaları tüm programları kapsayacak şekilde gözden geçirmektir (Blöndal vd., 2008, s. 10).

2011 yılında getirilen Parlamento Hizmet Değişikliği (Parlamento Bütçe Görevlisi) Kanunu (Parliamentary Service Amendment (Parliamentary Budget Officer) Act) ile Parlamento Bütçe Ofisi Departmanı (Departmant of the Parliamentary Budget Office) oluşturulmuştur ${ }^{2}$. Ofis siyasi açidan bağımsız olarak Parlamentoyu bütçe konusunda bilgilendirmekle görevlendirilmiştir. Bu doğrultuda bütçenin ve maliye politikalarının analizini partizan bir duruştan uzak şekilde yapması gerekmektedir (Parlamento Hizmet Değişikliği (Parlamento Bütçe Görevlisi) Kanunu, Bölüm 64B).

Parlamento Bütçe Ofisi Departmanının parlamento üyelerinden gelen politika önerilerinin maliyetleri veya bütçe ile ilgili herhangi bir hususun analiz isteklerini yerine getirmek, mali şeffaflığ arttırmak adına her seçim döneminden sonra büyük partilerin seçim taahhütlerinin mali etkileri hakkında rapor hazırlayıp yayınlamak, kamuoyunun bütçeyi ve mali politikaları daha iyi anlamasını sağlayacak araştırmalar yapmak ve yayınlamak temel görevleri arasında yer almaktadır Parlamento Hizmet Değişikliği (Parlamento Bütçe Görevlisi) Kanunu, Bölüm 64B ve Bölüm 64E).

\subsection{Güney Kore}

Güney Kore tarihinde ekonomik planlama ile bütçeleme arasında çok sıkı ilişki kuran ülkelerden biridir. Özellikle 1961 yılında kurulan Ekonomik Planlama Kurulu (Economic Planning Board - EPB) bu konuda önemli işlevler üstlenmiştir. Kurul Ekonomik Planlama Bürosu (Bureau of Economic Planning ile Bütçe Bürosundan (Bureau of Budget) oluşmuştur. Planlama ile bütçeleme arasındaki sıkı ilişkinin kurulmasında önemli işlevleri olan Ekonomik Planlama Bürosu) ve Bütçe Bürosu diğer bürolardan ayrılmaktaydı (Kim, 2014, s. 13). Kurul genel olarak ekonomik planların oluşturulmasında, bütçelerin hazırlanmasında ve hatta dış yardımların tahsisinde güçlü yetkilere sahipti. Öyle ki parlamento üyeleri, harcamacı bakanlıklar ve hatta devlet başkanı dahi kurul teknokratlarının kurallarına bağlı kalmak durumundaydılar. Bu durum doğal olarak bütçe hakkı, hesap verilebilirlik gibi hususların arka planda kaldığı bir yönetim sistemi içinde gelişmiştir (Kim, 2014, 26). Bunun da en önemli sebebi 1961 yılında yapılan askeri darbenin devlet yönetimi üzerinde meydana getirdiği değişiklikler olmuştur. Zira yönetim biçiminde meydana gelen gelişmelerden önce Bütçe Bürosu Maliye Bakanlığına bağlıydı. Sonrasında Ekonomik Planlama Kurulu oluşturulup ona bağlanmıştır. Bütçe Bürosunun kurula bağlanmasıyla birlikte yetkileri de genişlemiştir. $\mathrm{Bu}$ yetkiler arasında yıllık bütçe rehberinin hazırlanması, bakanlıklardan yıllık tekliflerin toplanması ve uygulanabilirliklerinin değerlendirilmesi yer almaktadır ${ }^{3}$ (Haggard, Kim ve Moon, 1990, s. 10, 18).

Kamu maliyesi alanında reformların yapılmaya başlandı ğı 2000'li yılların başında kurulan Kore Millet Meclisi Bütçe Ofisi bütçe hakkının ve hesap verilebilirliğin gelişimi konusunda önemli boşlukları doldurmuştur. Bütçe Ofisinin Planlama ve Yönetim Departmanı, Bütçe Analiz Departmanı, Tahminler ve Vergi Analiz Departmanı ve Ekonomik Tahmin Departmanı olmak üzere dört departmanı bulunmaktadır. Bütçe Analiz Departmanı bütçe teklifleri, fonlar, ulusal mali yönetim, konsolide mali denge, devlet borcu, ülke içindeki veya dışındaki mali sistemler, büyük hacimli ulusal programlar, orta ve uzun vadeli mali talep ile hükümetin performans yönetimini kapsayacak şekilde araştırmalar yapmak ve analizler gerçekleştirmek için görevlendirilmiştir. Ayrıca burada sayılan görevlerle ilgili olmak üzere Ulusal Meclis üyelerinden veya komisyonlarından gelen istekler üzerine araştırma ve analiz gerçekleştirmek Bütçe Departmanının bir diğer görevidir. Bu görevler daha ayrıntılı olarak Bütçe Analiz 
Departmanını oluşturan Bütçe Analiz Danışmanı, Bütçe Analiz Koordinasyon Bölümü, Endüstriyel Bütçe Analiz Bölümü, Sosyal Bütçe Analiz Bölümü, İdari Bütçe Analiz Bölümü, Ekonomik Endüstriyel Program Değerlendirme Bölümü, Sosyal İdari Program Değerlendirme Bölümü ve Kamu Kurumu Değerlendirme Bölümü görevleri arasında yer almaktadır (NABO, 2019).

4 Ekim 2006 tarihli ve 8050 sayılı Ulusal Maliye Kanunu (National Finance Act) ile bütçe süreci ve bu süreçte dikkate alınan bütçe ilkeleri ile ilgili hususlar ele alınmıştır. Yıllık ilkesinin benimsendiği Güney Kore'de bütçe harcamalarının sadece ilgili oldukları yılın gelirleri ile finanse edilebileceği belirtilmektedir (3. madde). Y1llık ilkesinin yanı sıra hükümetin mali yönetimini beş yıllık periyodlarla hazırlaması gerekmektedir (7. madde). Mali yönetim planının içinde mali yönetimin amaçları, orta ve uzun dönem mali tahminler, bütün alanlar için kaynak tahsisi planları, ihtiyari ve zorunlu harcamaların artışlarıyla ilgili tahminler, hazine gelir artışları ve vergi yükü ile ilgili tahminler ve Cumhurbaşkanı kararı ile eklenebilecek diğer hususlar yer almaktadır (7. madde).

8050 sayılı Ulusal Maliye Kanununun 16. maddesi bütçenin hazırlanması ve yürütülmesi süreçlerinde dikkate alınması gereken bütçe ilkelerini ele almaktadır. İlkelerden birincisi hükümetin mali sağlamlığı güvence altına almak ve insanların üzerindeki yükü en aza indirmek için her türlü çabayı gösterme durumunu ifade etmektedir. İkinci ilkeye göre hükümet hazine harcamalarının ve vergi harcamalarının ${ }^{4}$ sonuçlarını geliştirmelidir. Üçüncüsü, vatandaşların bütçe sürecine katılmalarını ve saydamlığı sağlamak üzere hükümetin gerekli önlemleri alması gerekmektedir. Dördüncüsü, hükümet bütçenin hem erkekler hem de kadınlar üzerindeki etkilerini değerlendirecek ve elde ettiği sonuçları bütçenin oluşturulmasına yansıtacaktır. Aynı kanunun 17. maddesi ise sayılan ilkelerden ayrı olarak "kapsamlılık" (genellik) ilkesi olarak isimlendirilmiştir. Buna göre bütün gelirler bütçe gelirleri kısmında ve giderler de bütçe harcamaları kısmında yer almalıdır ${ }^{5}$.

Hükümet toplam bütçenin en fazla yüzde birini ihtiyat akçesi/yedek fon (reserve fund) olarak kullanabilmektedir. İhtiyat akçesinin tutarı belirlendikten sonra hükümet bunu bütçeye yansıtılmayan veya bütçeyi aşan harcamalar için kullanabilmektedir (8050 sayılı Ulusal Maliye Kanunu, 22. madde). Bütçe yıllık olarak hazırlanmasının yanında birden fazla yıla yayılabilecek işler için yıllık ilkesi dikkate alınmayabilmektedir. Ancak toplam miktarın ve ayrıca yıllık ödenecek taksitlerin Ulusal Meclis tarafindan onaylanması gerekmektedir. Bununla birlikte birden fazla yıl ile kastedilen beş yıldır. Ancak projenin ölçek büyüklüğüne ve ülkenin mali durumuna göre oluşabilecek istisnai durumlar gerektirdiğinde bu süre on yıla kadar çıkabilmektedir (8050 sayılı Ulusal Maliye Kanunu, 23. madde). Yıllık ilkesi çerçevesinde ele alınabilecek bir diğer husus da ilgili yılda harcama bütçesinden gerçekleşmeyen harcamaların takip eden yıla aktarılmasıdır. Böyle bir durumun gerçekleşmesi için Ulusal Meclis'in ön onayı gerekmektedir (8050 sayılı Ulusal Maliye Kanunu, 24. madde).

Güney Kore'de kamu maliyesi alanında 2003 ile 2007 arasında önemli reformlar yapılmıştır. Orta vadeli harcama çerçevesi ${ }^{6}$ (Ulusal Mali Yönetim Planı - National Fiscal Managament Plan), yukarıdan-aşağıya bütçeleme, performans yönetimi, dijital bütçeleme ve Ulusal Kamu Maliyesi Kanunu (National Public Finance Law) ile bütünleşmiş muhasebe sistemi yapılan reformların ana başlıklarıdır. Şeffaflığ arttırmak ve vatandaşların bütçe sürecine dahil edilmesi gibi hususlar konusunda da çalışmalar devam etmektedir (OECD, 2019, s. 207).

Kore'de orta vadeli mali planlar beş yıllık olarak hazırlanır ve bütçeleme sürecinde yıllık olarak güncellenerek toplam hükümet harcamaları ile harcamacı birimler (bakanlıklar) yıllık harcama tavanları belirlenir (Kim, 2010, s. 178). Orta vadeli mali planlara bağlı bütçeleme 2003 yılında girişilen reformlardan önce de denenmiştir. 1982 ve 1998 yıllarında orta vadeli mali planlar kabul edilmişse de bu planlar yıllık bütçeleme süreçlerinde dikkate alınmadıkları için vazgeçilmişlerdir. Bu sebeple 2003 yılından itibaren gerçekleştirilen orta vadeli mali planların başarısı ve sürdürülebilirliği kritik bir şekilde yıllık bütçelere bağlanmasına gayret edilmiştir. Bu da esasında çok yıllı bir perspektifin yıllık bütçelere bağlı olarak yürütülmesinin önemini ortaya koymaktadır. Kore'nin benimsediği İsveç modeli de yukarıdan aşağıya çok yıllı harcama tavanlarını uygulattı̆̆ından orta vadeli plan ile yıllık bütçeler arasında kritik bağlantılar meydana getirmektedir (Kim, 2010, s. 179).

Güney Kore 2005 yılında yukarıdan-aşağıya bütçelemeyi benimsenmeye başlamıştır. 2005 yılından önceki dönemlerde aşağıdan-yukarıya bütçeleme çerçevesinde harcamacı bakanlıklar ödenek taleplerini üst seviyeden belirlemekteydiler. Genellikle bir önceki yıl bütçesinin ortalama yüzde otuz 
kadar arttırılarak talep gerçekleşmekte ve sonrasında pazarlıklar başlamaktaydı. Yukarıdan-aşağıya bütçelemeye girişildikten sonra bu oran oldukça azalmış ve mali disiplinin sağlanmasına önemli katkılar sağlamıştır (Kim ve Park, 2006, s. 92).

Aylık bütçe gerçekleşmeleri konusunda rapor yayımlanan Güney Kore'de y1l ortası için bir rapor yayınlanmamaktadır. Yılsonu mali tabloları ise 10 Nisan'a kadar hazırlanır ve mali raporların denetimi 20 Mayıs'ta yapılır. Raporlar üzerine parlamenter denetim de Haziran ayı içinde gerçekleşmektedir. Bütçe ile ilgili hazırlanan raporların tamamı kamuoyuyla paylaşılmaktadır (OECD, 2019, ss. 207-208).

\subsection{Ingiltere}

İngiltere 1961 yılında yapmaya başladığı çok yıllı kamu harcamaları anketleriyle çok y1llı bütçeleme anlayışının öncüsü olarak kabul edilmektedir ${ }^{7}$. Çok yıllı bütçeleme ile politika yapıcılar bütçe politikalarına ilişkin orta vadeli bir bakış açısı elde etmeleri, harcamaların çok yıllı etkilerine odaklanmaları ve orta vadeli amaçlara ulaşmak için almaları gereken önlemleri analiz edebilmeleri sağlanmaktadır. Aynı zamanda bütçenin devamlılı̆̆ 1 ve istikrarı da çok yıllı bütçeleme anlayışının sağladığı diğer hususlardır (Boex, Martinez-Vazquez ve McNab, 2000, ss. 97-98).

Hükümetin orta vadeli mali stratejisi çok yıllı bütçeme anlayışının sürecine rehberlik etmektedir. Orta vadeli mali stratejinin belirlenmesi üzerine Maliye Bakanlığı başkanlığındaki Kabine Harcama Kabinesi çok yıllı dönem için toplam harcama limitlerini belirler. Limit belirlemeden sonra hükümet gelecek iki yıl için taahhüt ettiği harcamaları ortaya koyar ve yeni bir üç yıllık projeksiyon geliştirir (Boex, Martinez-Vazquez ve McNab, 2000, s. 98).

İngiltere'de bütçe beş yıllık ileriye dönük perspektiflere uyumlu hale getirilmektedir. Kamu Hesapları Komitesi (Public Accounts Commitee) Ulusal Denetim Ofisinin (National Audit Office) desteğiyle bütçe sonuçlarının izlenmesinde güçlü bir rol oynamaktadır. Parlamentonun yürütmenin getirdiği bütçe teklifini değiştirme konusundaki yetkileri çok sınırlıdır. Aynı zamanda bütçenin hazırlanmasında vatandaşların katılımı da çok sınırlıdır. Tüm bütçe harcamaları Hazinenin tek hesabı olan Konsolide Fon üzerinden yapılmaktadır. Performans bilgilerinin öncelikle organizasyon ve yönetim seviyesinde performans yönetimi ve hesap verilebilirlik aracı olarak kullanılmasına imkan veren yönetimsel performans bütçe sistemi benimsenmiştir. Bütçe tabloları hükümetin mali stratejileri, kısa vadeli riskler ve uzun dönemli mali sürdürülebilirlik konusunda bilgiler içermektedir. Bununla birlikte Bütçe Sorumluluk Ofisi mali riskler ve kamu maliyesinin uzun vadeli sürdürülebilirliği konusunda rapor hazırlayıp parlamentoya sunmaktadır (OECD, 2019, s. 253).

2010 yılında kurulan Bütçe Sorumluluk Ofisi ${ }^{8}$ (Office for Budget Responsibility) İngiltere kamu maliyesinin ve maliye politikalarının analizini yapmaktadır. Ofis yaptığı değerlendirme ve analizlerde bağımsız olarak hareket eder (Office for Budget Responsibility, 2019).

Bütçe Sorumluluk Ofisinin politika oluşturmak üzere kullanılan tahminleri öncelikle hükümetle paylaşı1ır. Ofis, böyle durumlarda hazırladığı raporları yayımlamadan önce hükümetin ilk tablolarını beklemektedir. Ancak ilk tablolar hazırlandıktan hemen sonra tahminlerine ilişkin raporu yayımlar. Bununla birlikte şeffaflığg arttırmak adına parlamento tarafından sorulan sorular ve verilen cevaplar, parlamentoya yazılı veya sözlü olarak sunulan kanıtlar, kendi yönetim düzenlemeleri hakkındaki bilgiler, Ofise yapılan veya Ofisten yapılan yazışmalar gibi birçok doküman kamuoyuyla paylaşılmaktadır (OECD, 2015, s. 251).

Bütçe Sorumluluk Ofisinin yanı sıra bir başka bağımsız kuruluş da Mali Araştırmalar Enstitüsüdür (Institute for Fiscal Studies - IFS). Enstitü 1969 yılında etkili maliye politikalarının geliştirilmesini desteklemek için kamuoyunun ekonomik konular üzerinde bilgilendirilmesini temel ilkesel amaç edinerek kurulmuştur. Her yıl Maliye Bakanının hazırladığ 1 bütçe teklifi ve reformları konusunda yaptığı analizleri yayımlamaktadır (Institute for Fiscal Studies, 2019).

Şeffaflık ve hesap verilebilirliğe katkı sağlayan bir uygulama da Hazine'nin her bir departman için, Kamu Hizmet Antlaşmaları (Public Service Agreements - PSA) olarak bilinen performans hedeflerinin yayınlanması taahhüdüdür. Anılan anlaşmalarla her departmandan kendisine ayrılan bütçe ile ne yapmasının beklendiği belirlenmektedir (Balls, 2019, s. 5). 
2002 y1lında hazırlanan Harcama Gözden Geçirme Notu (Spending Review White Paper) ile kamu hizmetlerin performansı konusunda bazı temel ilkeler benimsenmiştir. Birincisi, hükümet tarafından şeffaf çıktı odaklı ulusal amaçların belirlenmesidir. İkincisi, hizmet sunan kurumlara en yüksek esnekliği verecek şekilde yetki devrinin gerçekleşmesidir. Üçüncüsü, hesap verilebilirliği geliştirmek için bağımsız ve etkin denetim düzenlemeleri yapmaktır. Dördüncüsü de şeffaflığı arttırmak adına hem ulusal hem de yerel düzeyde daha iyi enformasyon oluşturmaktır (Noman, 2008, s. 4).

İngiltere hükümet çapında performans hedeflerinin oluşturulduğu performans yönetimini 2010 y1lından itibaren terk etmiştir. Böylece 2010 yılından sonra bütçenin performans esaslı yönelimi azaltılmaya başlanmıştır. Bunun yerine hükümet merkezi olmayan bir yaklaşım benimsenmeye başlamıştır. Alt ulusal hükümetler (sub-national government) ve departmanlar yaptıkları harcamalar ve elde ettikleri sonuçlar konusunda performans raporları yayınlamaya başlamışlardır (IMF, 2014, s. 94).

Parlamento iç tüzüğü ile belirlenen parlamento komiteleri (Seçilmiş Komiteler - Select Committees) bütçe sürecinde önemli rol oynar. Hükümetin her departmanından belirlenen komiteler, ilgili oldukları departmanın harcamalarını inceler. Ancak herhangi bir departmanla ilgili olmayan komiteler de bulunmaktadır. Bunlardan bir tanesi, parlamentonun en etkili komitelerinden olan Kamu Hesapları Komitesidir (Public Accounts Committee - PAC). Komitenin önemi kamu harcamalarını finanse etmek için parlamento tarafindan verilen ödeneklerin hesaplarını incelemekten gelmektedir (OECD, 2004, ss. 414-415).

Bütçenin gelir kısmının değiştirilmesi konusunda parlamentonun sınırlandırılmış bir yetkisi bulunmamaktadır. Ancak gelirlerin azalmasına yol açacak bir harcama değişikliği konusunda sınırlandırılmıştır. Harcamalar parlamentoda departman bazında onaylanmaktadır. İngiltere'de uygulanan Westminster yönetim sisteminin pratik bir sonucu olarak hükümetin genellikle parlamento çoğunluğunu da elinde bulundurması hükümetin önerdiği gelir ve harcama miktarının parlamentoda çok az değişmesi anlamına gelmektedir (IMF, 2014, s. 93).

\subsection{Kanada}

Kanada'da bütçe konusunda gerçekleşen reformlar konusunda önceki girişimlerin başarısız olmasından dolayı hızlıca yeni yöntemler aranarak yoğun çabalar gösterilmiştir. Ancak bunlar "yeni”" reform olmaları yönüyle eleştirilmektedir. Zira reform olarak getirilen yeniliklerin geçmiş uygulamalara dayandırılması bu eleştirilerin odak noktasını oluşturmaktadır (Good ve Lindquist, 2010, s. 105). Bütçe süreci ve hazırlanan tahminlerin parlamenterler tarafından anlaşılamaması Kanada bütçe sisteminin en fazla eleştirilen yönlerden birini oluşturmaktadır. Bu husus hazırlanan birçok raporda belirtilmekte ve parlamentonun kendisinden beklenilen görevlerini yerine getirebilmesi için anlaşılır, zamanlaması yapılmış ve sağlam temellerle hazırlanmış bilginin parlamenterlere sunulması gerektiği ifade edilmiştir ${ }^{9}$ (Lukiwski, 2019, s. 7).

2006 y1lında yürürlüğe giren Federal Hesap Verilebilirlik Kanunu (Federal Accountability Act) ile önemli reformlar gerçekleştirmiştir. Parlamento Bütçe Ofisi'nin (Parliamentary Budget Office) kurulması ile hükümet tahminlerinin ve bütçe planlamasının şeffaflı̆̆ 1 ve güvenirliği gelişmiştir. Genel Denetmen Ofisine (Office of the Auditor General) federal hükümetten kaynak alan tüm kişi ve kurumları denetleyebilecek yeni yetki ve kaynaklar sağlanmıştır. Bu yetki alanı içine tüm kamu özel sektör işbirlikleri de dahil edilerek hesap verilebilirlik ve şeffaflık güçlendirilmiştir. Ofis içindeki denetim komisyonları üyelerinin hükümet dışından atanmaları sağlanarak bağımsızlık sağlanmaya çalışılmıştır. Bakan yardımcıları da kendi departmanlarının denetim memurları olarak belirlenmişlerdir. Böylelikle parlamento karşısında, atanmışlar sorumluluk alanları ile ilgili sorulara cevap vermeleri konusunda sorumlu tutulmuşlardır (Good ve Lindquist, 2010, ss. 113-114).

2006 y1lında kurulan Parlamento Bütçe Görevlisi (Parliamentary Budget Officer - PBO) kamu maliyesi ile hükümetin yaptığ 1 tahminler konusunda ve ülkenin ekonomisinde meydana gelen gelişmeler üzerine bağımsız analizler yapan bir kurumdur. Ayrıca bir komitenin veya parlamenterin isteği üzerine Parlamento tarafindan yapılan tekliflerin maliyetlerini de tahmin eder. Parlamentoda yapılan bütçe görüşmelerinin/tartışmalarının kalitesini arttırmak, mali şeffaflığı ve hesap verilebilirliği geliştirmek temel amaçları arasında yer almaktadır. Federal ve diğer alt düzeyler için gelecek yetmiş yıllık süreyi kapsayacak mali sürdürülebilirlik raporlarının hazırlanması da diğer önemli görevleri arasında yer 
almaktadır. Kurum güçlü bir bağımsızlı̆ga sahip olmasına rağmen idari olarak Parlamento Kütüphanesine bağlıdır. (IMF, 2014, s. 22).

Parlamento Bütçe Görevlisi'nin önemli bir sorumluluğu da genel seçimlerden önce yapılan analizler hakkındadır. Siyasi partilerden veya Avam Kamarasının bağımsız üyelerinden gelen istek üzerine partilerin veya kişilerin seçim kampanyasında öne sürdükleri vaatlerin finansal maliyetlerini tahmin etmektir ${ }^{10}$ (Parliamentary Budget Office, 2019).

Merkezi yönetimin tamamı federal bütçe kapsamında yer almaktadır. Ancak merkezi yönetim bazı yetkilerini illerle paylaştı̆g için Kanada Emeklilik Planı (Canada Pension Plan - CPP) bütçenin dışında yer almaktadır (IMF, 2014, s. 24).

Parlamento hükümetin harcama teklifini değiştirmek istediğinde bunu sadece azaltma yönünde kullanır veya doğrudan reddeder. Ancak ödenekleri arttırmak gibi bir yetkisi yoktur. Dolayısıyla bütçe çoğu zaman hükümetin hazırladığı şekilde gerçekleşmektedir. Bütçe mali yıldan önce parlamentoya gönderilmekte, ancak ana tahminler (main estimates) ise genellikle mali yılın ilk üç ayında tamamlanmaktadır. Bu sürede özel bir ödenek kanunu ile ara dönem ödenekleri (interim supply for the main estimates) sağlanarak mali yılbaşından itibaren kamu hizmetlerinin aksamasının önüne geçilmektedir (IMF, 2014, ss. 24-25).

\subsection{Fransa}

1789 yılında gerçekleşen Fransız Devriminden sonra, yine aynı yılda Fransa Ulusal Meclisi tarafından kabul edilen Fransız İnsan ve Yurttaş Hakları Bildirisi demokrasi ve özgürlükleri pekiştiren maddeler içermektedir. Bu maddelerden bazıları bütçe hakkı, hesap verilebilirlik gibi bütçe ilkelerine dolaylı yollardan atıfta bulunmaktadır.

Bildirinin üçüncü maddesi iktidarın açık olarak ulustan kaynaklandığını belirtir. Buna göre hiç kimse ulustan kaynaklanmayan bir iktidar aracına sahip olamayacaktır. Dolayısıyla devlet idaresi için iktidarı ele alanlar yapacakları kamu harcamaları ve toplayacakları gelirleri dolayısıyla halktan zımni olarak izin almış olmaktadır. On altıncı madde de kuvvetler ayrılığı ilkesini benimseyerek bu hususun tamamlayıcısı olmuştur. Böylece yürütme yetkisini elinde bulunduranlar ile yasama yetkisini elinde bulunduranların ilkesel olarak birbirlerinden ayrı tutulması hedeflenmiştir.

Bildirinin altıncı maddesi yurttaşların bizzat veya seçtikleri temsilciler yoluyla kanunların oluşturulmasına katılma hakları olduğunu belirtir. Bu bağlamda çıkarılacak kanunların kamu harcaması veya kamu gelirleri ile ilgili olması hali bütçe hakkının tesisi anlamına gelecektir. Benzer doğrultuda düzenlenen on dördüncü maddede de vergilerin gerekliliğini tartışma, elde edilen vergi gelirlerinin kullanım alanlarını gözleme gibi haklar da bizzat yurttaşlar veya seçecekleri temsilciler aracılığıyla kullanabilecekleri haklar olarak sayılmıştır. Başka bir deyişle harcamaların yapılacağı yerlerin denetimi de sağlanmış olmaktadır.

Bildirinin on beşinci maddesi hesap verilebilirliği işaret etmektedir. Buna göre "Toplumun kamu görevlilerinden, görevleriyle ilgili olarak hesap sorma hakkı bulunmaktadır." denilerek kamu görevlilerin yapacakları iş ve eylemlerle ilgili olarak topluma hesap vermesi ilkesi benimsenmiştir.

Fransa'da 1990'ların sonlarına kadar birlik, tahsis, y1llık ve genellik olmak üzere dört temel bütçe ilkesi benimsenmiștir. Birlik ilkesi ile mali y1l boyunca bütün gelirlerin ve giderlerin tek bir dokümanda toplanması; tahsis ilkesi ile ayrılan ödeneğin sadece belirlenen amaç için kullanılması, yı1lık ilkesi ile bütçe ile ilgili tüm işlemlerin sadece mali yılla sınırlanması ve genellik ilkesi ile toplam gelirlerin toplam harcamaları finanse etmek için (adem-i tahsis) için kullanılması öngörülmüştür. 2000'li yılların başında yapılan reformlarla bütçenin bahsi geçen klasik ilkelerine yenileri eklenmiştir. Bunlar genel olarak mali saydamlık ve sorumluluk reformları başlıkları altında toplanabilir (Moretti ve Kraan, 2018, ss. 14-15).

Mali saydamlık ilkesi ile Parlamentonun bütçe sürecindeki rolünü arttırmak hedeflenmiştir. Mali saydamlıkla birlikte diğer ilkesel ve kurumsal düzenlemeleri düzenleyen kanun 2001 yılında yürürlüğe giren Bütçe Kanunlarının Anayasal Tüzüğü'dür ${ }^{11}$ (Constitutional Bylaw on State Budget Acts - Loi Organique de Lois de Finances) (Moretti ve Kraan, 2018, s. 15). Düzenlemenin iki öncelikli amac1 bulunmaktadır; kamu yönetimini performans yönelimli kılmak ve parlamenter gözetimi ön plana 
çıkarmak. Bu doğrultuda belirlenen programlara göre mali kaynakların dağıtılması sağlanmak istenmiştir. Parlamentoya sunulacak bütün programların her biri için toplam bütçe, amaç ve performans göstergelerinin açık olarak tanımlanmaları gerekmiştir. Bu süreçte kamu yöneticilerine kaynak tahsisatı konusunda daha fazla özgürlük sağlanmışsa ${ }^{12}$ da hesap verilebilirlikleri de arttırılmış ve bütçe sonuç odaklı hale getirilmiştir. Parlamento üyelerinin hükümet programlarını performans çerçevesinde değerlendirebilmeleri için her program için beklenen performans ile gerçekleşen performans karşılaştırması hakkında bilgilendirilmeye başlanmıştır. Ayrıca daha önce parlamento üyelerinin gelir azaltıcı ve gider arttırıcı tekliflerde bulunamayacağı konusundaki sınırlılık da gevşetilerek "ödeneklerin programlar arasındaki dağıtımını değiştirmeleri” mümkün hale getirilmiştir (Kusek ve Rist, 2004, s. 30).

Mali sorumluluk reformları harcama kuralları, gider değerlendirmeleri ve çok yıllı planlama ekseninde gerçekleşmiştir. Harcama kuralları devletin iradi harcama kuralları, sağlık harcamalarıyla ilgili harcama kuralları ve yerel yönetimlerle ilgili harcama kuralları olmak üzere üçe ayrılmaktadır. Gider değerlendirmelerinde mümkün olan tasarruf tedbirlerinin alınması, gelirlerin toplanmasında etkinlik, hizmet kalitesinin arttırılması ve idari prosedürlerin basitleştirilmesi merkezi yönetim düzeyinde ele alınmaktadır. Çok yıllı olma konusunda orta vadeli bakış açısıyla ve bütçe yılını aşacak şekilde yürütme organının bazı mali sorumluluklar altına alınması düşünülmüştür. Bakanlıkların bütçe yılı ile birlikte takip eden iki yıllık harcama tahminlerini de yapmaları zorunluluk altına alınmıştır (Moretti ve Kraan, 2018 ss. 15-19).

Mali Kanunlarla İlgili Organik Kanunla birlikte en az dört y1llı genel ekonomik ve mali görünümü, planlanan tedbirlerin mevcut politikalarla ilişkileri, her programın performans bilgisi ve vazgeçilen vergileri gösteren vergi harcamalarının tahmini bütçe kanunu ile birlikte sunulmaya başlanmıştır. 2009 yılında da merkezi yönetim bütçesi harcamaları daha detaylı olarak ele alan çok yıllı bütçe çerçevesi uygulanmaya başlanmıştır (Yılmaz ve Önal, 2019, s. 100).

Fransa Maliye Bakanlığı çatısı altında bütçe konusunda bir internet sitesi (budget.gouv.fr) oluşturulmuş ve bütçe konusundaki tüm gelişmeler gerçek zamanlı olarak bir zaman çizelgesi üzerinde gösterilmektedir. Zaman çizelgesi üzerinden geçen sürede meydana gelişmeler izlenebilmektedir. Sitede ayrıca aylık bütçe durumları grafiklerle gösterilmekte, takip eden yıl için bütçe prosedürü yer almaktadır. "Kamu parasını kim harcadı?" sorusunun altına yine bir grafikle yerel hükümetlerin, merkezi hükümetin ve sosyal güvenlik fonlarının yaptığı harcama miktarları gösterilmektedir.

Anılan internet sitesinde yer alan başka bir önemli husus performans alt göstergelerinin sunumudur. Sona eren bütçe yılında ulaşılan sonuçlar bu göstergelerde yer almaktadır. Öncelikle ilgili yılda belirlenen toplam performans alt gösterge sayısı ortaya konulmakta ve bütçe yılı boyunca bunlardan kaçının belirlenen hedefe ulaştığı, kaçının gelişimine devam ettiği, kaçında hiçbir gelişmenin yaşanmadığı gösterilmektedir. İstenildiği durumda programların detaylı performansına ulaşılabilmektedir. Ayrıca tüm programların amaçları, göstergeleri ve alt göstergeleri bakımında değerlendirilmekte ve nihai olarak genel bütçenin performans değerlendirilmesi ortaya konulmaktadır. Örneğin eğitim, adalet veya kamu maliyesi için yapılan toplam kamu harcamaları, toplam çalışan sayısı, belirlenmiş hedefler ve bu hedeflere yönelik gerçekleşen programların başarı dereceleri ve tüm bunlarla hedeflenen arasındaki farklar grafikler ve çeşitli görsel araçlarla kamuoyuyla paylaşılmaktadır.

\subsection{Güney Afrika}

1994 y1lında Güney Afrika'da post-apartheid ${ }^{13}$ hükümetin göreve gelmesi ile birçok alanda olduğu gibi mali alanda ve dolayısıyla bütçe konusunda da önemli reformların yapılması gerekmiştir (Hogan, 1996, s. 417). 1994 yılında demokratik bir sürece geçilinceye kadar bütçeleme sürecinde yaşanan olumsuzluklar, bütçenin belirsizliği, bütçenin mali dengeyi sağlamadaki yetersizliği, anayasal eksiklikler, harcamaların etkinlik ve verimlilik değerlendirmesinin sınırlılığı, bütçe sürecinden ve hesap verilebilirlik amaçlarından sakınılarak gerçekleşen harcamalar, şeffaflı̆̆ın olmaması bütçeleme konusunda belirgin olarak görülen sorunlardı (Fölscher ve Cole, 2006, s. 2). Demokratik sürece geçişle birlikte girişilen reformların altında yatan temel ilkeler (bu ilkeler bütçe sürecinin başlangıcından denetimine kadar olan tüm süreci kapsamaktadır) şunlar olmuştur (Fölscher ve Cole, 2006, s. 3):

- Kapsamlılık ve entegrasyon: Ulusal bütçe çerçevesi ülkedeki ulusal, eyalet ve yerel seviye için bütçe sürecini ve politikalarını koordine, entegre ve disipline etmektedir. 
- Politik gözetim ve politik önceliklere odaklanma: Öncelikler arasındaki seçimler nihai aşamada politiktir. Seçimlerin politik olması finansman seçeneklerinin hükümetin önceliklerine uygun olmasını ve politik gözetimin güçlendirilmesini sağlamak için siyasi ve idari uygulamaların entegrasyonunu yapılandırmayı gerektirir.

- Enformasyonun stratejik kullanımı: Reform süreci zamana yayılarak geliştirilip uygulanacaktır. Kaynakların kullanımı ve tahsisi ile ilgili elde edilecek bilgiler kamu politikalarının geliştirilmesi ve hesap verilebilirliğin uygulanması amacıyla kullanılır.

- Teşvikleri değiştirerek davranışı değiştirme: Sorumluluk (onaylanmış tavanlarda) harcama tercihleri konusunda harcamacı birimlere devredilir.

- Bütçe istikrarını ve öngörülebilirliğini sağlamak: Bütçe mekanizması belirsizliği yönetmek, fonlamayı ve politik tahmin edilebilirliği orta vadede arttırmak için çeşitli mekanizmalar içerir.

Güney Afrika'da 1998 y1lında orta vadeli harcama çerçevesi benimsenerek uygulanmaya başlanmıştır. Böylelikle harcamacı birimler hangi kaynakların kendileri için kullanılabilir olduğunu bilmelerine imkan sağlanmış ve böylece hükümet planlamaları daha güvenilir ve kesinlik kazanmıştır. Orta vadeli harcama çerçevesi belirlendiğinde harcamacı birimler kaynakların tahsisinde stratejik önceliklerin belirlenmesinde mali disiplinin de temin edilmesini sağlamaktadırlar. Bu bakımdan bütçe sürecinin iki temel amaca indirgemek mümkündür. Birinci amaç mali hedefleri belirlemek ve ikincisi amaç ise bu hedefler doğrultusunda stratejik önceliklere göre kaynakların tahsisini sağlamaktır (Mahlangu ve Mphela, 2011, s. 16).

Orta Vadeli Harcama Çerçevesi Güney Afrika'da belirgin amaçlar içermektedir. Birincisi, makroekonomik ve mali politikaların varlığı çerçevesinde hazırlanan harcama planlarının karşılanabilir bütçe programlarını temin etmesini sağlamak olarak belirtilmektedir. İkincisi, erken politika önceliklerinin temin edilmesi, rakip politika ve programların değerlendirilmesi ile mevcut ve orta vadeli planların eldeki uygun kaynaklarla eşleşmesi yapılmak suretiyle politika öncelikleri ile kamu harcamaları arasındaki bağı kuvvetlendirmektir (Fölscher ve Cole, 2006, s. 9).

Güney Afrika'da çok yıllı bütçeleme üç yıllık olarak hazırlanmaktadır; gelecek mali yıl ve takip eden iki yıllık dönem. Ancak Parlamento tarafından onaylanan sadece gelecek mali yılın bütçesidir. Takip eden iki yıllık bütçe tahminleri ise Parlamento tarafından onaylanmaz, ancak gelecek dönem bütçe tahminleri için bir temel veya gösterge niteliğindedir (Mahlangu ve Mphela, 2011, s. 16). Güney Afrika'da Parlamento tarafından kabul edilen bütçe önerileri Orta Vadeli Harcama Çerçevesi sürecinde dikkate alınmakta ve hazırlanmaktadır. Planlama ve politika arasındaki bağı güçlendirmek için alt program düzeylerine kadar tüm bütçe tahminleri üç yıllık periyodlar halinde hazırlanmaktadır (Fölscher ve Cole, 2006, s. 11).

Bütçenin Parlamentoda tartışılması geniş bir katılım ağıyla gerçekleşmektedir. Parlamentodaki tartışmalara örgütlü çıkar grupları, sivil toplum kuruluşları, medya ve vatandaşlar katılmaktadır. Böylelikle Parlamento sadece yürütmenin gelir ve harcama önerilerini incelemekle kalmamakta; aynı zamanda şeffaflığın olmasını da temin etmektedir (Mahlangu ve Mphela, 2011, s. 24). Bütçe gözetimi yıl içi izleme ve yılsonu izleme olarak Parlamento tarafından komiteler aracıllğıyla gerçekleştirilir. Her iki izleme sürecinde de örgütlü sivil toplum kuruluşları ve kamuoyu Parlamento komitelerinde yapılan sunumlarda veya medya aracılığıyla katılımda bulunurlar. Bu süreç bütçenin etkili ve verimli bir şekilde istenilen sonuçları meydana getirip getirmediğini belirleme konusunda önem taşımaktadır. Nihai bütçe dokümanların değerlendirilmesi Genel Denetmen (Auditor-General -AG) gibi bağımsız kurumlarca yapılmakta ve bu değerlendirmede belgelerin tutarlığı ele alınmaktadır. Genel Denetmen birimlerin mali yönetim, performans ve pozisyonlarını inceler. İncelemeden sonra y1lsonu belgelerinde mali durumun ve yönetimin durumu ile kalitesi hakkında görüşünü bildirir. (Mahlangu ve Mphela, 2011, ss. 25-26).

1996 Anayasasının 215. maddesi Güney Afrika'nın üç düzeyli yönetimlerinin (ulusal, eyalet ve belediye) tamamı için bütçe süreçleriyle ilgili hükümler içermektedir. Üç düzeyli yönetimlerin bütçe sürecinde şeffaflığ 1 ve hesap verilebilirliği geliştirecek, etkili bir mali yönetim sağlayacak önlem almaları gerektiği belirtilmiştir. Aynı maddenin ikinci fikrası bütçe kanununun içermesi gereken belirlemeleri (bütçelerin formu, bütçelerin ne zaman tablolaştırılacağı, bütçelerde gelirlerin kaynağının gösterilmesi ve önerilen harcamaların ulusal mevzuata uygun olacağı gibi), üçüncü fikra ise bütçelerin 
içermesi gerekenleri (gelir ve harcama tahminleri, beklenilen açığın finansman önerileri, takip eden yıl kamu borcunu arttıracak borçlanma ve kamusal yükümlülüklerin göstergesi gibi) göstermektedir.

Genel Denetmen kurumunun denetim alanı 1996 Anayasasının 188. maddesi ile belirlenmiştir. Merkezi idare, eyalet ve belediye yönetim birimlerinin tamamı ile özel kanunlarla, üç yönetim birimi tarafından, Ulusal Gelir Fonu veya Eyalet Gelir Fonu ile fonlanarak kurulan işletmelerin tamamı hiçbir istisna bırakılmayacak şekilde genel denetimin alanına dahil edilmiş ve anayasal olarak güvence altına alınmıştır.

\subsection{Isveç}

İsveç'te 1990'ların başlarında artan mali sorunlar dikkatleri bütçeleme sürecinin kurumsal yapısı ile kamu maliyesinin sonuçları arasındaki ilişkiye çekmiştir. 1995 yılında artan sorunlar nedeniyle Maliye Bakanlığı bu konuya çözüm olarak Parlamentoya iki fazdan oluşan planı sunmuştur. Öncelikle bütçe açığını azaltmak için harcamaların azaltılması ve gelirlerin artırılması hedeflenmiş̧ir. Ancak kurumsal yapının da bunu sağlamak ve sürdürebilir kılması için değiştirilmesi istenmiş̧tir. Aşağıdanyukarıya bütçeleme terk edilerek yukarıdan-aşağıya bütçeleme benimsenmeye başlanmış ve orta vadeli harcama tavanları belirlenmiştir. Takip eden yıllarda uygulaması devam eden bu değişiklikler neticesinde 1998 yılında bütçe açığı kapatılmış ve fazla vermeye başlamıştır (Kim ve Park, 2006, ss. 9091).

İsveç’te 1991 ve 1992 yıllarında yaşanan büyük finansal krizlerden sonra bütçeleme sürecini ve bağımsız bir mali politika konseyinin oluşturulmasını da ele alan önemli reformlar gerçekleşmiştir. Örneğin yukarıdan-aşağıya bütçeleme ile harcamaların kontrol altında tutulması amaçlanmıştır. Burada Parlamento tarafindan Maliye Komitesinin önerisi üzerinde hükümetin toplam harcama miktarı ve bunun harcama alanlarına dağılımı belirlenmektedir. Daha sonra harcama birimleri belirlenmekte ancak bütçe dengesi korunmaktadır. Yine bütçenin birlik ilkesini tesis etmek için bütçe dışı fon uygulamalarına izin verilmemesi, genellik ilkesini tesis etmek için gelirlere karşı harcamaların netleştirilmesinin yasaklanmas1, başka bir deyişle bütçe bütçenin brüt olarak gösterilmesi bütçeleme sürecinde dikkate alınan diğer hususlardır. Hükümetin tavan konusunda Parlamentoya sunması gereken bir diğer husus net borç verme, yani fazla hedef konusundadır. Bütçe Kanununda sayısal bir hedef bulunmamakla ve sunulan hedef Parlamento tarafinda değiştirilebilmekle birlikte pratikte 1997 yılından beri gayri safi yurtiçi hasılanın yüzde biri olarak uygulanmaktadır (Calmfors, 2015, s. 601).

Danimarka ve Hollanda gibi ülkelerde reel harcamalar üzerine tavanlar getirilirken İsveç’te merkezi idarenin nominal harcamaları üzerine çok yıllı tavanlar getirilmektedir (The World Bank, 2013, s. 22). Bütçe yılından üç yıl önce bağlayıcı toplam tavan belirlenmekte ve hükümet önerisi de belirlenen toplam bu limite uymak durumunda bırakılmaktadır ${ }^{14}$. Bütçenin kabinede görüşülmesinde Maliye Bakanı tarafından belirlenen ödenek miktarını az bulan bir bakanın kendi ödenek tahsisinin arttırılmasını istemesi halinde diğer tüm bakanları denk gelen tutarı toplam harcamalardan indirmek için ikna etmek durumundadır. Böylelikle toplam harcama tavanı aşılmamış olacaktır. Dolayısıyla ilk durumda ve harcama tavanı ${ }^{15}$ sınırları içinde Maliye Bakanı tarafından belirlenen ödenek miktarlarının değiştirilmesi zor olmaktadır (Ljungman, 2009, s. 16). Bu şekilde harcama tavanlarının belirlenmesinin bütçeleme sürecini güçlendirdiği ve finansmanı stabilize ettiği yönünde geniş bir konsensüs vardır (Ljungman, 2008, s. 38).

Harcama tavanlarının nominal olarak belirlenmesi enflasyonun beklentinin altında veya üstünde olması durumunda sorun yaşanmasına neden olabilmektedir. Nominal tavanlar belli miktarda belirsizlik içerse de tavanların nominal olarak belirlenmesinin nedeni şeffaflığ 1 sağlamaktır. Tavanların nominal olarak belirlenmesi tavanlar ile harcama tahminlerinin karşılaştırılmasındaki belirsizlikleri ve şüpheleri ortadan kaldırır. Ayrıca reel harcama tavanlarının belirlenmesi enflasyon ayarlamasının yapılmasını gerektireceği ${ }^{16}$ için bu konuda yaşanacak metodolojik tartışmayı ve deflatörün fırsatçı değişikliklerle kullanılması riskinden sakınmak için olumlu görülmektedir (Ljungman, 2008, s. 42).

Yıllık bütçe kanun tasarısında hükümet merkezi idarenin harcamaları için bir tavan önermeli ve bu gelecek üç yıl için yapılmalıdır. Bütçe yılını takip edecek ikinci ve üçüncü bütçe yılları için ön gelir tahmini ve harcama limiti önerisinde bulunmalıdır. Onaylanan harcama tavanının aşılması gibi bir risk söz konusu olduğunda hükümetin bundan kaçınmak için yetkileri içinde gerekli önlemleri alması veya 
Parlamentonun uygulaması için gerekli önlemleri önermesi gerekmektedir (2011:203 Sayılı Bütçe Kanunu, Bütçe Politika Hedefleri ve Rehberler, Birinci - Dördüncü Bölüm).

Çok y1llı bütçeleme kapsamında belirlenen harcama tavanları konusunda temel ilke bütünlüktür. Yukarıda değinilen bazı geçici istisnalar dışında merkezi idarenin gelirleri ile finanse edilen tüm kamu harcamaları belirlenen tavanın sınırları içinde kalmak durumundadır. Bütünlük temel ilkesine uygun olarak idari harcamalar, yatırım harcamaları, Avrupa Birliği'ne yapılan katkı ödemeleri, yerel idarelere yapılan bağışlar ve transfer ödemeleri harcamalar için belirlenen toplam tavana tabidir (Ljungman, 2008, s. 38).

Parlamento hükümetin önerisinden daha fazla oyla tamamen farklı bir alternatif bütçeyi onaylayabilir (OECD, 2019, s. 244). İsveç temsili demokratik bir siyasi yapısının yanında törensel yetkileri olan bir krallıktır. Ancak 1700'lerin sonu ile 1800'lerin başından itibaren güçler ayrılığ prensibi benimsenmiş ve bu doğrultuda bütçe konusunda yetki Parlamentonun eline bırakılmıştır (Sveriges Riksdag, 2016, s. 13). Hükümet Aracı'nın Mali Güç kısmının 7. maddesi Parlamento tarafından onaylanmamış hiçbir ödeneğin yapılamayacağını ve gelirin toplanamayacağını hüküm altına almaktadır. 8. madde ile hükümetin herhangi bir mali sorumluluk altına girmesi veya kredi alması Parlamento tarafindan hükümetin yetkilendirilmesi şartına bağlanmıştır.

Bütçe dönemi sırasında yayımlanan aylık raporlar anayasal bir zorunluluk altına alınmamakla birlikte, bütçe dönemi sonunda hazırlanacak yıllık rapor anayasal bir zorunluluk altına alınmıştır (Hükümet Aracı, Mali Güç kısmı, 10. madde). İsveç’te bütçe sonuçları aylık raporlar halinde hazırlanarak yayımlanmaktadır. Mali yıl sona erdikten sonra yılsonu mali tablosunun yayımlanması Nisan ayında, denetimi ise Mayıs ayında gerçekleşmektedir. Denetlenen mali tablonun Parlamento tarafından incelenmesi en geç 15 Haziran'a kadar yapılmak durumundadır (OECD, 2019, s. 243). Hazırlanan tabloların ve raporların kamuoyuna açık olması ve vatandaşlar tarafından kolaylıkla anlaşılabilecek şekilde hazırlanması şeffaflık ve ulaşılabilirlik açısından dikkat edilen temel hususların başında yer almaktadır (OECD, 2019, s. 244).

Harcamalar gelir başlıklarına karşlık gösterilerek bütçelendirilemez. Başka bir deyişle belli harcamalar için belli gelirler karşılık gösterilemez. Eğer Parlamento gelirin belli bir amaca taahhüdüne karar verirse, ödenek üzerindeki karardan farklı olarak, bu gelir bütçenin gelir başlıklarının altında bütçelendirilmez ve raporlandırılmaz. Bununla birlikte, gelir vergisi her durumda bütçenin gelir başlıkları altında bütçelendirilmek ve raporlanmak durumundadır. Bununla birlikte gelir ve karşılık gelen harcama da bütçelendirilmez ve ödenek başlıkları altında raporlandırılmaz. Eğer toplam harcamanın belli bir kısmı da bu şekilde gelir gösterilerek karşılanıyorsa bu harcamanın denk gelen kısmı için de aynı süreç geçerlidir. Ancak toplam harcamanın bir kısmı benzer şekilde gelir gösterilerek karşılanmış ve fakat harcamanın hangi kısmına denge geldiği belirsiz ise bunun bütçelendirilmesi ve raporlanması gerekmektedir (2011:203 Sayılı Bütçe Kanunu, Bütçeleme, Altıncı Bölüm).

Ödenek tavanları belirlenmiş olmakla beraber bazı özel durumlarda bir ödeneğin geçici olarak, toplam ödeneğin en fazla yüzde onuna kadar aşılmasına imkan verilmektedir. Bu durumlarda ödenek aşım tutarı kadar kaynak takip eden yıl indirilmektedir (2011:203 Sayılı Bütçe Kanunu, Bütçeleme, Sekizinci Bölüm).

Bütçe yılı içinde kullanılmayan ödenekler yeni yılla birlikte silinmemekte, takip eden yıllarda kullanılabilmektedir. Ödenek bütçeleştirildikten sonra en az iki y1l boyunca kullanılabilmektedir (2011:203 Sayılı Bütçe Kanunu, Bütçeleme, Onuncu Bölüm). Y1lı bütçe kanununda ve Bahar Mali Politika Kanununda hükümet hem cari bütçe yılı hem de takip eden üç yılı kapsayacak şekilde makroekonomik tahminler, merkezi yönetimin gelir ve harcama, borçlanma gereği konularında tahminler oluşturur. Bu bakımdan cari bütçenin, başka bir deyişle yürürlükte olan bütçe Bahar Mali Politika Kanunu ile revize edilmekte ve tahminlerle gerçekleşenler arasında önemli bir fark olması halinde bunun nedeni belirtilmektedir (2011:203 Sayılı Bütçe Kanunu, Takip ve Tahmin, Birinci Bölüm - Üçüncü Bölüm).

Hükümet idare ettiği veya sahip olduğu varlıklardan Parlamentoya karşı sorumludur. Hükümetin hesap verilebilirliği merkezi idare tarafından yapılan girişimleri ve merkezi idarenin borçları ile mali taahhütlerini de kapsamaktadır. Her yıl vergi harcama hesaplarının Parlamentoya sunulması da 
hesap verilebilirlik kapsamında değerlendirilebilir (2011:203 Sayılı Bütçe Kanunu, Hesap Verilebilirlik ve Denetim, Birinci Bölüm - Dördüncü Bölüm).

Merkezi idarenin yıllık raporu en geç 15 Nisan'da Parlamentoya sunulmak durumundadır. Raporda yer alması gereken hususlar 2011:203 Sayılı Bütçe Kanunu'nun Hesap Verilebilirlik ve Denetim (Accountability and Auditing) başlıklı onuncu kısmının altıncı bölümünde yer almaktadır. Hükümetin hesap verilebilirliğini güçlendirmek için y1llık raporda eklenmesi gereken belgelerden biri de İsveç Ulusal Denetim Ofisi (Swedish National Audit Office - SNAO) tarafından yapılan gözlemlere karş1lık olarak hükümetin aldığ 1 önlemlerin sunumudur. Böylece Ulusal Denetim Ofisi tarafindan eksik görülen bir husus varsa ve buna karşı hükümet nasıl önlemler almışsa bu yıllık raporda gösterilmektedir.

İsveç'te mali konularda değerlendirme yapan kurum İsveç Mali Politika Konseyi'dir (Swedish Fiscal Policy Council). 1 Ağustos 2007 tarihinde kurulan Konsey Güney Kore, Kanada, ABD ve Avustralya gibi örneklerinin aksine yürütme organının altında yapılanmıştır (Trapp, 2011, s. 5). Konsey'in görevleri arasında hükümet tarafından önerilen ve Parlamento tarafından onaylanan mali ve iktisadi politika amaçları üzerine değerlendirmeler yapmak yer almaktadır. Bu hedefler arasında kamu maliyesinin uzun vadeli sürdürülebilirliği, bütçe fazla hedefi, harcama tavanı ve mali politikanın ekonomideki döngüsel gelişmelerle tutarlılığ yer almaktadır. Konsey'in görev alanına ayrıca hükümetin bütçe kanunlarının açıklığını incelemek de yer almaktadır. Konsey görev alanına giren hususlarla ilgili gerçekleştirdiği incelemeleri İsveç Mali Politika raporuyla raporlamaktadır (FPR, About the Swedish Fiscal Policy Council, 2020). Yilda bir kez hazırlanan ve yayımlanan raporların (Fiscal Policy Reports 2009-2019) ilk sayfasında Konsey'in hükümetin bir ajansı olduğu, ancak hükümetin mali politikasını bağımsız olarak değerlendirdiği vurgulanmaktadır. Ayrıca Parlamentonun hükümet politikasını değerlendirirken Konsey tarafından hazırlanan raporun temel alındığı belirtilmekte ve böylece esasında Parlamentoya yardımcı bir kurum gibi çalıştı̆̆ izlenimi verilmektedir.

\subsection{Norveç}

Norveç Parlamentosunun anayasal olarak belirlenen görev ve yetkileri arasında vergi gibi kamusal yükümlülükleri onaylamak veya kaldırmak, borç artışına karar vermek, ülkenin parasal sistemini denetlemek, hükümetin harcamalarını finanse edecek gerekli paranın uygunluğuna karar vermek, Kraliyet ve hanedanı için yıllık olarak tahsis edilecek ödenek miktarı ve Kraliyete ait mülkleri belirlemek, Devlet Konseyinin (Council of State) kayıtlarını ve tüm kamusal raporları ve dokümanları teslim almak, devlet hesaplarının incelenmesi ile ilgili prosedürü belirlemek, bu hesapların yıllık olarak incelenmesini sağlamak için beş denetçi atamak (hesapların yılsonundan itibaren altı ay içinde denetçilere sunulması gerekmektedir) yer almaktadır (Norveç Anayasası, 75. madde).

Norveç Parlamentosunun basit çoğunlukla hükümetin önerisinde sınırsız değişiklik yapma yetkisi bulunmaktadır. Geçmişte, getirilen yeni harcamaların gelir karşılığı gösterilmeksizin veya başka harcamaları azaltmaksızın bütçenin parlamenter adaptasyonu neticesinde bütçe dengesi rutin şekilde kötüye gitmekteydi. 1997 yılında yapılan bütçe reformu ile Parlamento onayı mali disiplini güçlendirecek yukarıdan-aşağıya (top-down) prensibi benimsenmeye başlanmıştır. Reformla birlikte bütçe Parlamentoya gönderildikten sonra Mali ve Ekonomik İşler Daimi Komitesine (Standing Committiee on Finance and Economic Affirs - SCFEA) havale edilerek burada bütçe toplamı ve mali politika çerçevesinde incelenmeye başlanmıştır. Komitedeki incelemeden sonra yirmi iki sektörün harcama tavanından oluşan toplam harcama üzerine hazırlanan öneri ve gelir tahmini ile birlikte bütçe adaptasyon için Parlamento'ya sunulmaktadır. Parlamento onayından önce, aynı sektördeki harcama tavanını değiştirmeksizin yerini tutacak bir azaltma gösterilerek ödenek artışı gerçekleştirilebilir. Başka bir deyişle, bütçe henüz Parlamento tarafından onaylanmadan önce, bir sektör komitesi eğer ödenek artışı talep edecekse karşıllğında başka bir ödenekten (ancak aynı sektörden) azaltma göstererek bunu isteyebilecektir. Böylece ödenek artış talebi kabul edilse dahi sektör toplam ödeneğinde herhangi bir değişiklik meydana gelmeyecektir (Ljungman, 2009, s. 19).

Y1l içi düzeltmelerde ödeneklerin değişimi için Parlamento onayı gerekmektedir. Ancak beklenmeyen olayların gerçekleşmesi durumunda ödeneklerin belirli limitler dahilinde artırılmasına Kral'ın içinde bulunduğu Devlet Konseyi karar verebilir. Parlamento onayından önce karşılanması gereken "kaçınılmaz ihtiyaçlar" söz konusu olduğunda daha fazla ödenek artışına da karar verilebilmektedir. Ancak Parlamento ön onayı olmaksızın gerçekleştirilen bu ödenek artışların mümkün 
olan en yakın zamanda Parlamentonun onayına sunulması gerekmektedir. Bununla birlikte bütçe revizyon teklifleri yılda iki kez, Mayıs ve Kasım aylarında Parlamento onayına sunulmaktadır (Mundal, 2008, s. 28, 35).

Parlamentodaki görüşmeler, çoğunluk sağlandığı durumlarda kapalı oturumlarda gerçekleşebilmektedir. Bütçe görüşmeleri konusunda herhangi bir istisna yapılmadığı için, bütçe görüşmelerinde de Parlamento çoğunluğunun kararı ile kapalı oturumlar gerçekleştirilebilir (Norveç Anayasas1, 84. madde).

Merkezi idarenin tüm birimleri y1llık denetime tabi tutulmaktadır. Harcamalar, gelirler, yükümlülük ve varlıklar denetimin konusuna girmektedir. Hükümet tarafından mali tablolar takip eden yılın Nisan ayı sonuna kadar hazırlanmaktadır. Genel Denetmen Ofisinin (Office of the Auditor General) raporu da aynı yılın Kasım ayında hazırlanmaktadır. Dolayısıyla mali tabloların hazırlanması ile denetiminin tamamlanması arasında geçen süre yedi aydan daha azdır (Mundal, 2008, s. 28).

Devlet Konseyi üyeleri (bakanlar) Norveç Parlamentosu veya ona bağlı organları tarafından ele alınan bir konuyla ilgili istenilen her türlü bilgiyi Anayasal olarak sunmak durumundadır. Konsey üyelerinin ilgili konu hakkında yanlış veya yanıltıcı bilgi sunmaları Anayasal olarak yasaklanmış durumdadır (Norveç Anayasası, 82. madde). Dolayısıyla bütçeleme süreciyle ilgili Parlamento tarafından harcamacı bakanlıklardan veya Maliye Bakanından istenilen ve bütçe ile ilgili tüm bilgilerin tam ve doğru bir şekilde alınabilmesi Anayasal güvence altına alınmıştır.

Norveç'in önemli petrol kaynaklarına sahip olması ve sayılı petrol üreticisi ve ihracatçısı olması dolayısıyla petrol işlerinin de bütçe sürecinin dahil olduğu şeffaflık ilkesine göre yönetilmesi önem taşımaktadır. Petrol faaliyetlerinden elde edilen gelirler ve bu faaliyetlerin sürdürülmesi için yapılan harcamalar bütçe içinde gösterilmektedir. Ancak petrol sektöründen gelen toplam net gelirler bütçeden doğrudan 2006'dan önceki ismi Petrol Fonu (Petroleum Fund) olan Hükümet Emeklilik Fonu-Global'e (Government Pension Fund-Global) aktarılmaktadır. Petrol dışı bütçenin açık vermesi durumunda ise gerekli tutar mali bütçeye geri aktarılarak bütçe dengesi sağlanmaktadır (Mundal, 2008, s. 40).

Net petrol varlıkları ve gelecekte hükümetin petrol faaliyetlerin elde edeceği net gelirler ulusal bütçe dokümanlarında yer almaktadır. Bütçe dokümanlarında ayrıca petrol dışı bütçe dengesi ve Hükümet Emeklilik Fonundan (Petrol Fonu) transfer miktarı gösterilmektedir. 2007 yılından itibaren Fon faaliyetleri konusunda daha detaylı bilgilerin, performans ve yatırımları konusunda belgelerin yayımlanmasına başlanmıştır (Mundal, 2008, s. 40).

Norveç Parlamentosu sadece gelecek mali yılın bütçesini onaylar. Bununla birlikte Norveç'in mevcut sistemi demografik değişiklikleri ve yatırım programlarını dikkate almaktadır. Sonraki yıllar için yapılan çoğunlukla mekanik tahminlerdir ${ }^{17}$. Ancak yeni bütçe dokümanları arasında gelecek üç yıllık projeksiyonlar yer almaktadır (Anderson, Curristine ve Merk, 2006 ss. 16-17).

\subsection{Gürcistan}

Gürcistan bütçeleme sürecinde dikkate alınması istenilen bütçe ilkeleri 2935 sayılı Bütçe Kanununun dördüncü maddesinde işlenmiştir:

- Kapsamlılık: Buna göre bütçenin tüm gelir ve harcamalarıyla birlikte bütçe dengesinin bir bütün olarak bütçede yer alması gerekmektedir.

- Şeffaflk: Otoritenin temsilci (yasama) organına sunulacak bütçe tasarısının görüşme prosedürleri/süreci kamuoyuna ve medyaya aç1k olarak gerçekleşmesi gerekmektedir. Onaylanan bütçelerin ve onların Yürütme/İcra Raporlarının (Execution Reports) yayımlanması gerekmektedir. $\mathrm{Bu}$ süreçte bütçe hakkındaki bilgilerin bireyler ve şirketler için kolayca erişilebilir olması esastır.

- Hesap Verilebilirlik: Bütçeleme sürecindeki tüm katılımcılar performansları ve bütçede gösterilen bilgilerden dolayı sorumlu tutulmalıdır.

- Bağımsızlık: Gürcistan'da devlet, otonom cumhuriyet ve yerel yönetim bütçelerinin bağımsızlığı kendi gelirlerine sahip olmaları, bütçe dengesini kendilerinin sağlaması, 
harcamalarını belirleme bağımsızlığının verilmesi ile sağlanır. Ancak bu bağımsızlık Gürcistan yasal sınırları içinde gerçekleşmelidir.

- Birlik: Tüm seviyedeki bütçeler için birleştirilmiş bütçe sınıflandırma kodlarının, muhasebe sisteminin, devlet mali kontrolü ilkelerinin kullanılması gerekmektedir. Görüldüğü üzere genel manada devletin tüm gelir ve giderlerin tek bir bütçede olmasını ifade eden birlik ilkesinden farklı bir durumu ifade etmektedir.

- Genellik: Bütçe kanununda önceden öngörülenler dışında genel harcamaları finanse edecek tüm gelirlerin kullanılmasını ifade etmektedir. Buna ilave olarak hiçbir gelir, bağışlar hariç, belirli ve özel harcamalar için kullanılmamalıdır. Bütçe ile ilgili olan hiçbir kuruma, özel kanunları olanlar hariç olmak üzere, kendi amaçları doğrultusunda gelir toplamasına izin verilmez.

- Konsolidasyon: Devlet Hazinesinin genel muhasebe sistemi içinde tüm seviyelerdeki bütçe harcamalarının ve gelirlerinin konsolidasyonu, Gürcistan yasaları içinde harcamaların ödenmesi, Hazinenin ve Gürcistan Ulusal Bankasının genel muhasebe yönetimi bu ilke kapsamında değerlendirilmektedir.

Bütçe tasarısında harcamaların artışına, gelirlerin azalmasına veya yeni yükümlülüklerin getirilmesine Parlamento tarafından karar verilebilmektedir. Ancak bu durumda hükümetin onayının alınması gerekmektedir (Gürcistan Bütçe Kanunu, 20. madde). Bu durum bütçe tasarısı hükümet tarafından Parlamentoya sunulmak üzere hazırlanırken düşünülmemiş harcama alanlarının veya yeni harcama alanı gerektirecek durumların söz konusu olması halinde bütçeye esneklik kazandırmaktadır ${ }^{18}$. Ancak bütçe dengesinin hükümet tarafından teknik olarak daha iyi düşünülmesi de göz önünde bulundurularak bu değişiklik hükümetin rızasına bağlamıştır.

Ödenek tahsis disiplinin bozulmasını önlemek adına ödeneklerin kurumlar arası aktarımına ancak yıllık bütçe kanununda yer verilmişse izin verilebileceği hüküm altına alınmıştır. Ancak yukarıda belirtildiği üzere bütçenin işleyişine esneklik sağlamak için programlar/alt programlar arasında ödenek aktarımı gerektiği durumlarda bunun Maliye Bakanlığının onayıyla gerçekleştirilebileceği belirtilmiştir. Bununla birlikte belli bir oransal sınırlama getirilerek bütçe disiplinini bozacak aktarımların önüne geçilmek istenmiştir (Gürcistan Bütçe Kanunu, 31. madde).

Bütçeye çok y1llı perspektif Temel Veri ve Yönlendirmeler Belgesi (Basic Data and Directions Document) ile verilmektedir. Ülkenin orta vadeli makroekonomik ve mali tahminleri üzerinden kalkınmanın temel planı olan Belge dört yıl için (bütçe yılı ve takip eden üç yıl) hazırlanmakta ve yıllık olarak güncellenmektedir. Belgenin oluşturulmasında harcamacı bakanlıkların hazırladıkları orta vadeli öncelikler dikkate alınmaktadır (Ministry of Finance of Georgia, 2019, s. 11, 14).

Gürcistan Anayasasının 66. maddesi bütçe kurumunu ele almaktadır. Maddede son olarak bütçeleme süreci ile ilgili prosedürün kanunla belirlemesi gerektiği vurgulanmakla birlikte kanunun hazırlanması aşamasında bazı anayasal bağlayıcılıklar belirlenmiştir. Belirlemelerin birincisi bütçenin onaylanmasında meclis üye çoğunluğunun temel alınmasıdır. Temel Veri ve Yönlendirmeler (Basic Data and Directions - BDD) Parlamentonun komisyonları tarafından incelendikten sonra bütçe tasarısının Parlamentoya sunulmasına yetkili tek organ hükümet olarak belirlenmiştir. Anayasa ayrıca hükümet tarafından Parlamentoya sunulacak bütçe tasarısı için de süre sınırını belirlemiştir. Buna göre bütçe tasarısının bütçe yılının bitimine en geç üç ay kala Parlamentoya sunulması gerekmektedir. Ancak geçmiş yıl bütçesi kesinleşmiş sonuçlarının (kesin hesabının) onaylanması için en geç bütçe yılının bitmesine beş ay kala Parlamentoya sunulması gerekmektedir.

Parlamento bütçe tasarısı üzerinde yapacağı herhangi bir değişiklik dolayısıyla hükümetten izin almak zorundadır. Anayasa hükümete aynı zamanda Parlamento eğer ilave harcama talebinde bulunursa bu ilave harcamayı finanse edecek kaynağın da gösterilmesini talep etme hakkı vermektedir. $\mathrm{Bu}$ bakımdan Parlamento dilediği değişikliği, hükümetin izin vermesi suretiyle gerçekleştirebilmektedir. Ancak bu değişiklik ilave bir harcama yapmayı gerektirdiği durumlarda Parlamentonun ilave harcamanın fon karşılığını göstermek durumundadır. Parlamento gerekli gördüğü durumlarda bütçe harcamalarını arttıracak veya gelirleri azaltacak veyahut hükümeti yeni sorumluluklar altına sokacak kanunlar çıkarabilme yetkisini bütçe yılı içinde de kullanabilir. Ancak aynı şekilde bu durumda da hükümetin onayını/iznini almak durumundadır. 
Hükümetin hazırladığı bütçe tasarısında geçmiş yıla kıyasla Parlamentoya tahsis edilen fonda bir azalmanın söz konusu olabilmesi için Parlamentonun izin vermesi gerekmektedir. Anayasa ayrıca ödeneğin nasıl tahsis edileceği konusunda Parlamentoya bağımsız karar verme yetkisi sunmuştur.

Bütçenin incelenmesi ve kamu kaynaklarının etkin ve hesap verilebilir şekilde kullanılmasını sağlamak için Devlet Denetim Ofisi (State Audit Office) Anayasanın 69. maddesinde anayasal bir kurum olarak yer edinmiştir. Ofisin işlevsel bağımsızlığı anayasal güvence altına alınmış ve sadece Parlamentoya karşı hesap verilebilir kılınmıştır. Hükümetin bütçe faaliyetleri konusunda Parlamentoya rapor hazırlayıp sunması gerekmektedir. Böylelikle Anayasasının kendisine atfedilen "Parlamentonun kamu kaynakları üzerindeki kontrolünü sağlama" görevini de yerine getirmiş olacaktır. Ofisin yetki alanı, yapısı ve diğer ilgili prosedürün organik kanunla ${ }^{19}$ düzenlenebileceği hüküm altına alınarak diğer kamu kurumlarına kıyasla oldukça yüksek bir seviyede değerlendirilmiştir.

Gürcistan'da bütçe analizi yapan bağımsız mali kurum Parlamento Bütçe Ofisidir (Parliamentary Budget Office of Georgia - PBOG). 1997 yılında oluşturulan kurum 2005 yılından itibaren Parlamentonun Bütçe ve Maliye Komisyonuna (Committee for Budget and Finance of the Parliament of Georgia) karşı hesap verme sorumluluğu altına alınmıştır. 2014 yılında kanuni düzenlemelerle uluslararası iyi uygulamalar çerçevesinde daha güçlü hale getirilmiş ${ }^{20}$ ve Ofis sadece Parlamento Başkanının başkanlık ettiği denetleme kuruluna karşı hesap verebilir hale getirilerek bağımsızlığı ve objektifliği garanti altına alınmıştır (Parliamentary Budget Office of Georgia, 2020).

2014 yılında kanuni değişikliklerle Parlamento Bütçe Ofisinin görev/yetki alanı genişletilmiştir. Bütçenin plan aşamasında kapsamlı analizinin yapılması; bütçe kanununda yapılan değişikliklerin incelenmesi; hükümet politikalarının mevcut mali kurallarla ve orta vadeli mali sürdürülebilirlikle uyumunun değerlendirilmesi; orta vadeli mali tahminlerin oluşturulması, kamuya açı ve önceden tanımlanmış kriterlere göre maliye alanında araştırma yayınlarının yapılması, kendi makroekonomik tahminlerinin yapılmasının yanında resmi tahminlerin bütçe planlaması üzerindeki etkilerinin değerlendirilmesi Ofisin görevleri arasında yer almaktadır. Ofis ayrıca ilgili bütçe yılında hazırlayacağı raporlar konusunda takvim hazırlamakta ve bunu yayımlamaktadır. Takvimde aylık, üç aylık, yıllık inceleme raporlarının yayımlanacağı tarihler belirtilmektedir. Ayrıca Ekim, Kasım ve Aralık aylarında bütçe tasarısı üzerine hazırlanan raporların da yayımlanacağı tarihler gösterilmektedir (Parliamentary Budget Office of Georgia, 2020).

Bütçeleme süreci ile ilgili bazı hususlar Gürcistan Parlamentosu Prosedür Kurallarında (Rules of Procedure of the Parliament of Georgia) yer alan Parlamentonun Bütçe Hakkı başlığ altındaki on beş maddede yer almaktadır. Örneğin Parlamento Bütçe ve Maliye Komisyonu (Budget and Finance Committee) aracılığıyla bütçenin genel ve tutarlı bir gözetimini yapması, Maliye Bakanının her üç aylık bütçe gerçekleşmelerini toplam itibariyle Parlamentoyu bilgilendirmek amacıyla sunması, üç aylık raporların Bütçe ve Maliye Komisyonu tarafından incelenmesi ve Komisyonun talebi halinde kamu kurumlarının ilave bilgi sunması zorunluluğu, Devlet Denetim Ofisinin tarafından yıllık değerlendirme/durum raporunun Parlamentoya sunulması için belirlenen azami süreler bu hususlardan bazılarıdır (Parliament of Georgia, 2019, ss. 152-155).

Gürcistan'da 2015 y1lından itibaren Vatandaş Rehberi (Citizen's Guide) yayımlanmaktadır. Rehber vatandaşların kolaylıkla anlayabilecekleri bir dille hazırlanmakta, program amaçları ve bütçe hakkında bilgi sunmaktadır. Rehber genel anlamda vatandaşlara hükümetin aktiviteleri konusunda bilgi sunmakta, bütçe planlaması ve gerçekleşmesi gibi konularla ilgilenmelerini hedeflemektedir. Vatandaş Rehberi içerik olarak öncelikle bütçe kavramı, program bütçe, program, alt program gibi kavramsal bilgiler sunmakta ve ardında Gürcistan bütçe sistemi anlatılarak temel alınan bütçe ilkeleri belirtilmektedir. Kamu mali yönetiminin ve dolayısıyla denetimin, raporlamanın nasıl işlediği anlatıldıktan ve ülkenin bütçe ilkelerine uyum açısından uluslararası karşılaştırmalarına yer verildikten sonra hükümetin izlemek zorunda olduğu mali kurallar gösterilmektedir. Son olarak ilgili yıl bütçesi özet rakam, tablo ve grafiklerle ele alınıp incelenmektedir (Ministry of Finance of Georgia, 2019, ss. 122). 


\subsection{Filipinler}

Filipinler 1987 Anayasasının 6. maddesi Mevzuat Departmanı'nı düzenleyen otuz iki bölümden meydana gelmektedir. Bu maddede kanunların hazırlanması, onaylanması ve yürürlüğe girmesi için gerekli anayasal düzenlemeleri içermektedir. 6. maddenin yedi paragraftan oluşan yirmi beşinci bölümü bütçe konusundaki anayasal hükümleri ele almaktadır. Buna göre Devlet Başkanı tarafindan önerilen bütçe ödeneklerinin Kongre tarafından arttırılmasına izin verilmemektedir. Bunun dışında kalan bütçenin şekli, içeriği ve hazırlık yönetimi kanunla belirlenecektir. Özellikle belirli ödeneklerle ilişkili olmayan herhangi bir hükmün genel ödenekler (bütçe) kanununa eklenmesine izin verilmemektedir. Yürürlüğe girecek hükmün operasyonu (işleyişi) da ilişkili olduğu ödenekle sınırlı olmak zorundadır. Bir diğer anayasal sınırlama da Kongre ödenekleri konusundadır. Buna göre diğer kamu departmanları veya ajansları için ödeneklerin onaylanması süreci nasıl işliyorsa Kongre ödenekleri için de aynı prosedürün takip edilmesi kesin bir şekilde ifade edilmektedir. Böyle bir hükümle Kongrenin bütçe ödenekleri konusunda diğer kurumlardan bir farkı olmadığı anayasal seviyede vurgulanmaktadır.

Anayasaya göre özel ödenek tahsisatı yapılabilmekte, ancak amacının ve Ulusal Haznedar (National Treasurer) tarafindan onaylanan hangi fonla destekleneceğinin belirlenmesi veya bunu finanse edecek gelir teklifiyle bu özel ödenek teklifinin yapılması gerekmektedir. Ödenek aktarmaları kesin bir şekilde yasaklanmıştır. Ödenek aktarımına izin veren kanun kabul edilememektedir. Bununla birlikte, Devlet Başkanı, Senato Başkanı, Temsilciler Meclisi Başkanı, Anayasa Mahkemesi Başkanı, Anayasa Komisyonlarının başkanları kanunla genel ödenekler (bütçe) kanununda yer alan herhangi bir bütçe kalemindeki tasarrufu başka bir bütçe kalemine aktarabilir. Görüldüğü üzere sayılan kişilerin ödenekleri kendileriyle ilgili olan ofislerin bütçe kalemleri arasında aktarma yapma yetkisi sınırlı bir şekilde sağlanmıştır. Bir bütçe kaleminde tasarruf olması durumunda ve kanuni bir dayanağın mevcudu halinde ödenek aktarması yapabilmelerine izin verilmiştir.

Anayasa özel amaçlarla vergi toplanmasına imkan vermektedir (1987 Anayasası, 6. madde, yirmi dokuzuncu bölüm). Özel amaçla toplanan fonların sadece belirlenen amacı gerçekleştirmek için toplanması esastır. Ancak belirlenen amaç gerçekleştikten veya yapılmasından vazgeçildikten sonra kalan fon genel hükümet gelirlerine transfer edilebilmektedir.

Bütçeleme sürecinde değinildiği üzere 1987 Anayasasının Mevzuat Departmanı başlıklı 6 . maddesinin yirmi beşinci bölümünün son paragrafı bütçenin mali yılbaşından önce yürürlüğe girmediği durumda geçmiş y1l bütçesinin yürürlüğe girmesini emretmektedir. Ancak yeniden yürürlüğe giren bütçe sadece toplam harcama limitini göstermektedir. Bununla birlikte geçmiş yıl bütçesinde yer alan ve tamamlanan projelere tahsis edilen kaynaklar hususunda herhangi bir sinırlama getirmemektedir. Yeniden yürürlüğe giren geçmiş yıl bütçesi Devlet Başkanına kaynakların tahsisi konusunda diğer harcama kalemlerini arttırma yetkisi vermektedir (Blöndal, 2010, s. 18).

Filipinler'de orta vadeli harcama çerçevesi Bütçe ve Yönetim Departmanının içinde bulunduğu bir süreçle belirlenmektedir. 1999 yılında orta vadeli harcama çerçevesi uygulanmaya başlamışsa da analitik bir araç olmaktan ziyade çok yıllı harcama tavanlarını sabitlemesi ve bu şekliyle Kongrenin onayına sunulması bunu orta vadeli harcama çerçevesinden ziyade çok yıllı bütçelemeye benzetiyordu. Kongre de bütçeleme sürecinde anayasal yetkisini gasp ettiği gerekçesiyle bu uygulamayı 2006 yılında yeniden düzenleninceye kadar reddetmiştir. 2006 yılında süreç tekrar ele alınarak orta vadeli harcama çerçevesi, gelecek yıl ve takip eden iki yılı da kapsayacak şekilde, analitik bir araç olarak kullanılmasına başlanmıştır (Blöndal, 2010, s. 12).

Filipinler'de 2007 yılında Bütçe ve Yönetim Departmanı tarafından Çıktılar Kitabı (Book of Outputs) hazırlanmaya başlamıştır. Çıktılar Kitabı bütçeyi ve bütçeleme sürecini açık, ölçülebilir ve doğrulanabilir performans göstergeleri ve hedefleri belirlemeye yöneliktir. Kitapta "ne yapıldı?", "ne yapılıyor?" ve "ne yapılması gerekir?" hususlarını gösteren performans ölçüm ve hedefler matrisi yer almaktadır (Blöndal, 2010, s. 15). Ülkede uygulanan bütçeleme sistemi Sonuca Dayalı Bütçeleme (Results-Based Budgeting) sistemidir. Bu sistem kapsamında performans esaslı sözleşme ve bütçeleme (Performance-Based Contracting and Budgeting) uygulanmaktadır. Bir performans sözleşmesi ile hükümet ile departmanlar (veya dış sağlayıcılar) arasında harcama miktarı ile üretim miktarı konusunda belirlenen hedefler yasal sözleşme haline gelmektedir. Bu sözleşmeler, Devlet Başkanı ile departman başkanları arasında gerçekleşen pazarlıklar veya departmanların yıllık performans hedeflerinin detayları 
şeklinde performans sözleşmeleri formunda olabilmektedir (Department of Budget and Management, 2012, s. 9).

Senato üyeleri ulusal çapta (nation-wide basis), Temsilciler Meclisi üyeleri de bölgesel çapta seçildiği için bütçenin hazırlanması sürecinde Senatonun mali sorumluluğa daha bağlı olduğu ileri sürülmektedir. Bu bakımdan genellikle Senatoda yapılan değişikliklerin önemli kısmı Temsilciler Meclisinde yapılan değişikliklerin tersi şeklinde gerçekleşmektedir. Bütçe teklifinin hem Temsilciler Meclisindeki Ödenekler Komisyonundaki görüşmeleri hem de Senatodaki Maliye Komisyonundaki görüşmeleri kamuya açık olarak gerçekleşmektedir. Ancak İkili Meclis Konferans Komitesindeki görüşmeler, yani hem Senatonun hem de Meclisin önerisinin mutabık kılınmaya çalışıldığı komitede görüşmeler kamuoyuna kapalı olarak gerçekleşmektedir (Blöndal, 2010, s. 20).

Anayasanın 6. maddesinin yirminci bölümüne göre Kongre ile ilgili hesapların kamuya açı olması, Denetim Komisyonu ${ }^{21}$ (Commission on Audit) tarafından incelenmesi ve her üye için yapılan harcamanın ayrıntılı olarak listelenip kamuoyuyla paylaşılması gerekmektedir.

Anayasanın 9. maddesinin D başlığı Denetim Komisyonunun Kongre dışındaki kamu kurumlarının denetimini düzenlemektedir. Anayasa hükmüne göre Denetim Komisyonunun; tüm gelirleri, harcamaları, fon ve varlıkların kullanımını, tutulan emanet hesaplarını, devletin sahipliğinde veya kontrolünde olan şirketleri denetleme ve inceleme yetkisine sahiptir. Ayrıca bunların Denetim Komisyonunun yargılama alanının dışına çıkarılmasına izin verecek bir kanuni düzenlemeye izin verilmemektedir. Bu kapsamda hazırlanan ve mali durumla birlikte hükümetin operasyonlarını da içeren yıllık rapor Kongreye ve Devlet Başkanına sunulmaktadır.

Filipinler Denetim Komisyonu 2012 y1lında Doğu Asya ve Pasifik Sosyal Hesap Verilebilirlik A $\breve{1}$ (Affiliated Network for Social Accountability in East-Asia and the Pacific - ANSA-EAP) ile ortaklaşa Vatandaş Katılımcı Denetim (Citizen Participatory Audits) uygulamasını ${ }^{22}$ başlatmıştır. Vatandaş Katılımcı Denetimin konusu olacak kamu projeleri Denetim Komisyonu tarafindan seçilmektedir. Seçilecek kamu projelerinin yüksek değerli ve yüksek etkili olmasına, ayrıca dört ay veya daha kısa sürede düzgün olarak denetlenebilecek projeler olmasına özen gösterilmektedir. Yüksek değerli ve yüksek etkili projeler aşağıdaki kriterler bazında belirlenmektedir (Tan, 2019, s. 5):

- Projenin insanların günlük hayatındaki öneminin ve aciliyetinin derecesi.

- Projenin maliyeti ve yolsuzluk karşısındaki kırılganlığı.

- Projeden etkilenen coğrafi ve demografik alanın kapsamı.

- Anlaşmazlık, mülkiyet ve yaşam riski.

- Planlanan yararlanıcıların yaşamlarında beklenen iyileşme.

Yukarıdaki kriterler çerçevesinde belirlenen kamusal projeler denetim konusu yapılmakta ve vatandaşların katılım gösterdiği ekiplerle denetim gerçekleştirilmektedir. Projenin bölgesel büyüklüğüne göre birden fazla ekiple de denetim gerçekleşebilmektedir. Her ekipte Denetim Komisyonunun denetmenleri ve vatandaşlar yer almaktadır. Ancak vatandaşlara genel olarak anket yapmak, envanter almak, fiziki muayene ve basit ölçümler yapmak gibi daha az teknik görevler verilmektedir (Tan, 2019, s. 6).

\section{Sonuç}

Bütçe ilkeleri bir ülkede uygulanacak mali politikaların da temel normunu belirleyen önemli unsurlardır. Ülkeye yapılacak yabancı yatırımlardan ülke içindeki tüketim davranışlarına kadar bir dizi ekonomik kararın üzerinde doğrudan veya dolaylı bir etki göstermesi kaçınılmazdır. Hatta kimi durumlarda bazı bütçe ilkelerinin dolaylı olarak temel hak ve özgürlüklere yaptığı göndermelerden dahi bahsedilebilir. En yalın hali ile bütçenin bir kanun olarak tanımlanması dahi bunun hukuki etkilerinin kaçınılmaz olduğunu göstermek bakımından önem taşımaktadır. Diğer taraftan bütçenin üzerine oturtulduğu temel sac ayakları olan ilkeler kanuni güvence altına alınarak ekonomik, sosyal ve siyasal güvence sağlanmaya çalışılmaktadır. Zira iktidar aygıtını ve bunun politikalarını yürütecek bürokrasiyi finanse eden yegane araç bütçedir. Milli ekonominin içindeki kamu kesiminin payını da ifade eden bütçe büyüklüğü itibariyle tüm ekonomik kararlar üzerinde önemli etkiler meydana getirmektedir. 
Çalışmada ele alınan ülkelerin bütçeleme sürecinde bağlı kaldıkları ilkeler değişiklik göstermekle birlikte genel olarak bağlı kaldıkları bazı kritik bütçe ilkeleri olduğu görülmektedir. Bunlar özellikle yürütme aygıtının kontrol ve denetim altında tutulmasına, vatandaşların ve yasama organının bilgi sahibi olmasına yönelik ilkeler olduğu dikkat çekmektedir. Dolayısıyla ülkelerin gelişmişlik seviyelerinden bağımsız olarak yasa koyucuların aynı endişeleri paylaştıkları söylenebilir. Özellikle 2. Dünya Savaşından sonra bütçenin artan fonksiyonlarına bağlı olarak ziyadesiyle teknik ve karmaşı bir belge hüviyetine bürünmesi ve kamu kesiminin sürekli olarak büyümesi bahsi geçen endişelerin temel sebebidir. Bu durum yasama organının hesap sorucu yönünü ön plana çıkartırken yürütme organının ve bürokrasinin hesap verici konumunu sağlama almaya çalışan düzenlemeleri gündeme getirmektedir. Ülke örneklerinden de görüldüğü üzere teknoloji ve bilişimde meydana gelişmelerden önemli ölçüde faydalanmaya gidildiği görülmektedir.

Ülkeler tek tek incelendiğinde diğer ülkelere kıyasla ayrıştıkları temel noktalardan biri mevzuatlarının kapsamlı olarak hazırlanmasıyla ilgilidir. Nitekim bazı ülkelerde mevzuat kapsamının kurumsal gelişmelerle desteklenmesi durumunda diğer ülkelerden daha iyi bir dereceye sahip olabilecekleri tespit edilmiştir. Diğer bir nokta uygulamanın benimsenmesiyle ilgilidir. Dikkatle incelendiğinde bazı ülkelerin bütçe ilkelerine doğrudan atıf yaparken bazılarının bunu genel uygulamalar içine aldıkları gözlemlenmektedir. Dolayısıyla bu tespit ayrışmanın diğer noktasının söylem ve eylem arasındaki farklılığa dayandığını göstermektedir. Zira örnek uygulamalardan bazıları doğrudan herhangi bir bütçe ilkesine atıf yapmadığı halde uygulamanın genel çerçevesi ortaya konulduğunda birçok bütçe ilkesinin benimsenmiş olduğunu göstermektedir. Buradan yola çıkılarak son tahlilde iyi bir bütçe ilkesi uygulamasının mevzuatla güvence altına alınmış, kurumsal gelişmeyle desteklenmiş, uygulayıcılar tarafından benimsenmiş ve açık, sade ve anlaşılır bir şekilde açıklanmış olması gerektiği ifade edilebilir. 


\section{NOTLAR}

${ }^{1}$ Talep edilen bilginin verilmesi başka bir kanunun çiğnenmesine yol açacaksa idare bilgi vermek zorunda değildir.

${ }^{2}$ Ofisin kurulması kanuni düzenlemeden bir yıl sonra, yani 2012 yılında gerçekleşmiştir.

${ }^{3}$ Kurul 1994 yılında Ekonomi ve Hazine Bakanlığının bünyesine alınmıştır.

${ }^{4}$ Burada anılan vergi harcamaları 8 Şubat 1999 tarihli ve 5825 sayılı Özel Vergilendirmenin Sınırlandırılması Kanununun (Restriction of Special Taxation Act) Vergi Harcama Bütçesinin Hazırlanması başlığını düzenleyen 142 (2) maddesinin birinci fikrasında belirlenmiştir.

${ }^{5} 8050$ sayılı Ulusal Maliye Kanununun 53. maddesi kapsamlılık (genellik) ilkesinin istisnalarını içermektedir. Tesislerden elde edilen gelirlerin bu tesisler için kullanılması, yatırımlar dolayısıyla yabancılardan sağlanan kredi kullanımı, borç ödemelerinde yaşanan dalgalanmalar (faiz değişimi, kur dalgalanması veya erken ödemeye gitme gibi) dolayısıyla harcama bütçesinin aşılması bu istisnalara örnek olarak verilebilir.

${ }^{6}$ Orta vadeli harcama çerçevesi beş yıllık olarak hazırlanır ve tavanlar yıllık olarak revize edilir. Kamu kurumların orta vadeli harcama çerçevesi hazırlamaları için rehber Ekonomi ve Maliye Bakanlığı tarafindan yayımlanır (OECD, 2019, s. 208).

${ }^{7}$ Harcamaların çok yılı limitlerle bağlanması konusunda da İsveç ve Hollanda gibi ülkelerle birlikte öncü konumda yer almaktadır (Balls, 2019, s. 5).

${ }^{8}$ Bütçe Sorumluluk Ofisinin kurulması ilk olarak Eylül 2008 yılında gündeme gelmiştir (OECD, 2015, s. 242).

${ }^{9}$ Konu hakkında son dönemlerde hazırlanan raporlardan bazıları şunlardır: 2003 yılında yayımlanan Meaningful Scrutiny: Practical Improvements to the Estimates Process, 2012 y1linda yayımlanan Strengthening Parliamentary Scrutiny of Estimates and Supply ve 2019 yılında yayımlanan Improving Transparency and Parliamentary Oversight of the Government's Spending Plans (Lukiwski, 2019, s. 8).

${ }^{10}$ Bahsi geçen kuruma benzer yetkilere sahip bir diğer kurum da 2013 yılında Mali Hesap Verilebilirlik Görevlisi Kanunu (Financial Accountability Officer Act) ile kurulan Mali Hesap Verilebilirlik Ofisidir (Financial Accountability Office - FAO). Üyeleri mecliste bulunan her partiden seçilen birer kişiden oluşmaktadır. Sorumluluk ve görevleri aynı olmakla birlikte Ofis sadece Ontario Yasama Meclisi için çalışmaktadır (FAO, 2019).

${ }^{11} \mathrm{Bu}$ düzenleme Mali Kanunlarla İlgili Organik Kanun (LOLF) olarak da bilinmektedir.

${ }^{12}$ Sağlanan özgürlüğün temel amacı programda belirlenen hedef ve performans göstergelerini gerçekleştirmektir. Bütçe kanununda belirlenen tavanlar dahilinde çok yıllı taahhütlere girmeleri de mümkün hale getirilmiştir (Moretti ve Kraan, 2018: 15).

${ }^{13}$ Apartheid politikalar çok sık olarak beyazların yararına tasarlanmışlardı ve bu da kaynakların tahsis sürecinde kendini gösteriyordu. Örneğin bütçeden ayrılan eğitim harcamalarından beyazların çocuklarına ayrılan para siyahi çocukların dört katından fazlaydı (Hogan, 1996: 419).

${ }^{14}$ Belirlenen harcama tavanının aşılması riski söz konusu ise hükümetin aksiyon alması veya Parlamentonun harekete geçmesi için aksiyon önermesi gerekmektedir (Calmfors, 2015, s. 601).

${ }^{15}$ Harcama tavanı sınırları içinde merkezi idarenin tüm harcamaları ve emeklilik sistemi yer alırken ulusal borcun faiz ödemeleri yer almamaktadır (OECD, 2019, s. 243).

${ }^{16}$ Harcama tavanlarının nominal olarak belirlenmesi enflasyon tahminlerin isabetli olması için hükümeti teşvik etmek gibi bir fayda da sağlamaktadır. Ayrıca kamu personelinin maaş ve ücret ödemeleri bütçenin önemli bir kısmını oluşturmakta ve bu tür harcamalar yıllık enflasyonist düzenlemelerde iyileştirilmektedir. $\mathrm{Bu}$ durumda büyük enflasyonist farkın olmadığ dönemlerde nominal bütçe tavanları önemli sorun olmamaktadır (Ljungman, 2008, s. 43). 
${ }^{17}$ Hükümet için gelecek yılların tahmininin mekanik olarak görülmesinin altında yatan neden mali kuraldır. Bahsi geçen mali kural pratik anlamda orta vadeli açık kuralı olarak görülmektedir. Buna göre petrol dışı bütçe açı̆̆ı Fon varlıklarının bütçe yılı başındaki değerinin yaklaşık yüzde dördüne kadar çıkabilecektir (Anderson, Curristine ve Merk, 2006: 13).

${ }^{18}$ Gürcistan'da acil durumların söz konusu olduğu durumlarda Parlamentoya Acil Durum Karş1lık Bütçesi (Emergency Response Budget) onaylama yetkisi verilmektedir. Hükümet tarafından tasarısı hazırlanan Acil Durum Bütçesi acil durumlar veya ülkeye yönelik düşmanlıkların söz konusu olması durumunda alınacak önlemlerin finanse edilmesini amaçlamaktadır (Gürcistan Bütçe Kanunu, 32. madde).

${ }^{19}$ Gürcistan'da organik kanun olarak yer alan konular arasında devlet bayrağı, resmi dil, devlet marşı gibi ancak Anayasanın değiştirilmesi ile düzenlenebilecek hususlar yer almaktadır. Bu bakımdan denetim kurumu bütçenin bir parçası olmakla birlikte daha fazla ön plana alındığı söylenebilir.

${ }^{20}$ OECD Bağımsız Mali Kurum İlkeleri (OECD Principles for Independent Fiscal Institutions) benimsenmiştir.

${ }^{21}$ Denetim Komisyonu anayasal güvence ile kurulan üç komisyondan biridir. Bağımsız çalışmalarının yanında üyelerinin sosyal ve ekonomik hakları ayrıntılı bir şekilde anayasal güvence altına alınmıştır. Başkan ve üyeler doğrudan Devlet Başkanı tarafından sadece tek sefer için atanmaktadır.

${ }^{22}$ Uygulama Avustralya hükümeti tarafından fonlanan "Kamu Denetim Sürecinin Şeffaflığını, Hesap Verilebilirliğini ve Vatandaş Katılımcılığını Sağlama" projesi kapsamında geliştirilmiştir (Tan, 2019, s. 7). 


\section{KAYNAKÇA}

Aksoy, Ş. (1993). Kamu bütçesi. Filiz Kitabevi.

Anderson, B., Currıstıne, T., \& Merk, O. (2006). Budgeting in Norway. OECD Journal on Budgeting, 6(1), 7-43

Baimyrzaeva, M., \& Kose, H. O. (2014). The role of supreme audit institutions in improving citizen participation in governance. International Public Management Review, 15(2), 77-90.

Balls, E. (2019). The political economy of public spending reviews: The UK experience since 1997. $M$ RCBG Associate Working Paper Series, 113. hks.harvard.edu/sites/default/files/centers/ $\mathrm{mrcbg} /$ files/113_final_V2.pdf

Biçer, Ş., \& Şahin, M. (2008, 8-9 Ekim). Editoryal not. Bütçe Sürecinde Parlamentonun Değişen Rolü Uluslararas1 Sempozyumunda sunulan bildiri, Afyonkarahisar.

Blöndal, J. R., Bergvall, D., Hawkesworth, I., \& Deighton-Smith, R. (2008). Budgeting in Australia. OECD. Journal on Budgeting, 8(2), 1-64.

Boex, L. F. J., Martinez-Vazquez, J., \& McNab, R. M. (2000). Multi-year budgeting: A review of international practices and lessons for developing and transitional economies. Public Budgeting \& Finance, 20(2), 91-112.

Calmfors, L. (2015). The Swedish macroeconomic policy framework. J. Pierre (ed.) içinde, The Oxford handbook of Swedish politics (ss. 593-613). Oxford University Press.

Çağan, N. (2008, 8-9 Ekim). Modern bütçe sürecinde Parlamento'nun rolü. Bütçe Sürecinde Parlamentonun Değişen Rolü Uluslararası Sempozyumunda sunulan bildiri, Afyonkarahisar.

Department of Budget and Management. (2012). Organizational performance indicator framework: A guide to results-based budgeting in the Philippines. dbm.gov.ph/wp-content/uploads/2012/ 03/OPIF\%20Reference\%20Guide.pdf

Edizdoğan, N., \& Çetinkaya, N. (2015). Kamu bütçesi. (6. Baskı). Ekin Yayınevi.

FPR. (2020), About the Swedish fiscal policy council. fpr.se/english/swedishfiscalpolicycouncil/ abouttheswedishfiscalpolicycouncil/

Fölscher, A., \& Cole, N. (2006). South Africa: transition to democracy offers opportunity for whole system reform. OECD Journal on Budgeting, 16(2), 1-38.

Good, D. A., \& Lindquist, E. A. (2010). Discerning the consequences and 1ntegrity of Canada's budget reforms: a story of remnants and resilience. J. Wanna, L. Jensen, \& J. De Vries (Ed.) içinde: The reality of budgetary reform in OECD nations: Trajectories and consequences (ss. 91-121). Edward Elgar Publishing.

Haggard, S., Kim, B. K., \& Moon, C. (1990). The transition to export-led growth in South Korea, 195466. World Bank Working Papers, No: 546.

Hawke, L. (2007). Performance budgeting in Australia. OECD Journal on Budgeting, 7(3), 1-15.

Hemming, R. (2004). Policies to promote fiscal discipline, fiscal affairs department. IMF, https://pdfs.semanticscholar.org/50d8/0534fe981398b6a96e1434129471ce43f687.pdf?.ga=2.2 38563264.1166161578.1582202612-897877394.1582202612

Hogan, B. (1996). The budget process in South Africa: managing change. National Tax Association, 89, 417-422.

IMF. (2014). Budget institutions in G20 countires - Country evaluations. IMF Policy Paper, imf.org/external/pp/ppindex.aspx.

Institute for Fiscal Studies. (2019). Budget analysis, ifs.org.uk/tools_and_resources/budget.

Kim, J. (2014). The role of fiscal institutions for the sustained economic growth of Korea. Planning and Budgeting in Korea and Selected Countries. Korea Institute of Public Finance. 
Kim, J. M. (2010). Korea's four major budgetary reforms: Catching up with a big bang. J. Wanna, L. Jensen, \& J. De Vries (ed.) içinde: The reality of budgetary reform in OECD nations: Trajectories and consequences (ss. 174-192). Edward Elgar Publishing.

Kim, J. M., \& Park, C. K. (2006). Top-down budgeting as a tool for central resource management. OECD Journal On Budgeting, 6(1), 87-125.

Kıral, H., \& Akdemir, T. (2019). Bütçe hakkı kapsamında Türkiye'de ödenek aktarmalarının değerlendirilmesi. Sayıştay Dergisi, 112, 107-135.

Kusek, J. Z., \& Rist, R. (2004). Ten steps to a results-based monitoring and evaluation system. The World Bank Publication.

Ljungman, G. (2008). Expenditure ceilings - A survey. IMF Working Paper, WP/08/282.

Ljungman, G. (2009). Top-down budgeting - An instrument to strengthen budget management. IMF Working Paper, WP/09/243.

Lukiwski, T. (2019). Improving transparency and parliamentary oversight of the government's spending plans. Report of the Standing Committee on Government Operations and Estimates, publications.gc.ca/collections/collection_2019/parl/xc70-1/XC70-1-1-421-16-eng.pdf

Mahlangu, L., \& Mphela, N. (2011). The South Africa budgeting process. Budget Analysis Manual, 1631. Information Service Section.

Ministry of Finance of Georgia. (2019). Citizen's guide: Law on state budget, mof.ge/images/File/ guides/Citizens\% 20Guide\%20-\%202020\%20kanoni\%20ENG\%20LAST-04.pdf

Moretti, D., \& Kraan, D. (2018). Budgeting in France. OECD Journal on Budgeting, 18(2), 3-67.

Mundal, H. (2008). Public financial management performance report-Norway. Norwegian Agency for Development Cooperation, Norad Report, 12/2008.

NABO. (2019). Organization chart. National Assembly Budget Office, korea.nabo.go.kr/about/ organiza1.php\#tab2

Noman, Z. (2008). Performance Budgeting in the United Kingdom, OECD Journal on Budgeting, 8(1), $1-16$.

OECD. (2004). The legal framework for budget systems: An international comparison. OECD Journal on Budgeting, Special Issue.

OECD. (2015). United Kingdom. OECD Journal on Budgeting, 16 (2), 241-256.

OECD. (2019). Budgeting and public expenditures in OECD countries 2019. OECD Publishing.

Office for Budget Responsibility. (2019). What we do. https://obr.uk/about-the-obr/what-we-do/

Parliamentary Budget Office. (2019). The PBO at a glance. pbo-dpb.gc.ca/en/about--a-propos

Parliamentary Budget Office of Georgia. (2020). Role and functions. pbo.parliament.ge/about-us/roleand-functions

Parliament of Georgia. (2019). Rules of procedure of the parliament of Georgia. parliament.ge/en/ajax/downloadFile/131641/ROP_as_of_27_Dec_2018_ENG

Posner, P., \& Park, C. K. (2007). Role of the legislature in the budget process: Recent trends and innovations. OECD Journal on Budgeting, 7(3), 1-26.

Sahgal, V. (2008, 8-9 Ekim). Parliament's role: Budget formulation \& Execution and external audit \& Scrutiny. Bütçenin Değişen Rolü Uluslararası Sempozyumunda sunulan bildiri, Afyonkarahisar.

Sveriges Riksdag (2016). The constitution of Sweden: The fundamental laws and the riksdag act. The Riksdag Administration, Department for Parliamentary Documents. 
Şahin, D., \& Temur, Y. (2015). Kamu harcama yönetiminin yeni gündemi: Yukarıdan-aşağıya bütçeleme. Yönetim ve Ekonomi Araştırmaları Dergisi, 13(1), 143-164.

Tan, M. G. P. (2019). Audit in the Philippines - Pilot phase I (2012-2014). World Bank, Learning Note, No: 3.

Tandırcıoğlu, H. (2008, 8-9 Ekim). Bütçeleme sürecinde mali saydamlık - Mali açık ilişkisi. Bütçenin Değişen Rolü, Uluslararası Sempozyumunda sunulan bildiri, Afyonkarahisar.

Taşlıyük, A. U. (1964). Mali idare prensipleri ve tatbikatı: bütçe. İzmir İktisadi ve Ticari İlimler Akademisi Yayınlarından, Yayın No: 42, Ticaret Matbaacılık.

The World Bank. (2013). Beyond the anual budget: Global experience with medium term expenditure frameworks. World Bank Publications.

Trapp, L. V. (2011, June 7). The role of independent fiscal institutions [Konferans Sunumu]. Budgeting and Public Expenditure Committee Presentation to the OECD. htpss://researchgate.net/publication/228216322_The_Role_of_Independent_Fiscal_Policy_Ins titutions

Türk, İ. (1979). Maliye politikası amaçlar - araçlar ve çağdaş bütçe teorileri. (4. baskı). S Yayınları.

Yılmaz, H. H., \& Önal, M. (2019). Fransa'da kamu mali yönetim sisteminin yeniden yapılandırılmas1 ve 2008 küresel krizi sonrası dönemde uygulanan politikaların analizi. Amme İdaresi Dergisi, 52(1), 85-116.

Bütçe Dürüstlük Kanunu. (1998, 17 Nisan). (Say1: 22, 1998). https://www.legislation.gov.au/Series/C2 004A05333

Denetçi Genel Kanunu. (1997, 24 Ekim). (Say1: 151, 1997). https://www.legislation.gov.au/Series/C20 $\underline{04 \mathrm{~A} 05248}$

Filipinler Anayasası. (1987, 11 Şubat). https://www.officialgazette.gov.ph/constitutions/1987const itution/

Güney Afrika Cumhuriyeti Anayasası. (1996). (Say1: 108, 1996). https://www.gov.za/documents/ constitution-republic-south-africa-1996

Gürcistan Anayasas1. (Say1: 2071). http://parliament.ge/uploads/other/28/28803.pdf

İsveç Bütçe Kanunu. (2011). (Say1: 2011: 203). https://www.government.se/4b0eb3/contentassets /0d05209c49824d86bd3d977f4cfaa568/2011203-budget-act

Kamu Yönetimi, Performans ve Hesap Verilebilirlik Kanunu. (2013, 29 Haziran). (Sayı: 123, 2013). https://www.legislation.gov.au/Details/C2017C00269

Norveç Anayasası. (1814, 17 Mayıs). https://www.stortinget.no/en/In-English/About-the-Storting/TheConstitution/

Parlamento Hizmet Değişikliği. (Parlamento Bütçe Görevlisi) Kanunu (2011, 4 Aralık). (Sayı: 170, 2011). https://www.legislation.gov.au/Series/C2011A00170

Ulusal Maliye Kanunu. (2006, 4 Ekim). (Say1: 8050). https://elaw.klri.re.kr/eng_service/lawHistory. $\% 20$ do?seq $=458 \&$ hseq $=40922$ 